نشريه تحقيقات كاربردى علوم جغرافيايى، سال بيست و يكم، شماره بَو، زمستان . If

تأثير گَردگرى بر كيفيت زندَى روستاهاى سواحل درياى عمان

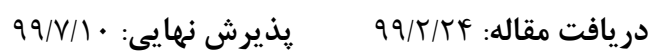

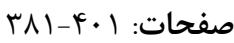

على منظم اسماعيل يور: عضو هيئت علمى و استاديار جغرافيا و برنامهريزى روستايى دانشخاه پِيام نور تهران، ايران'.

Email: monazzam.ali.1350@gmail.com

جִكيده

تردشكَرى نقش مهمى در توسعه روستايى دارد. كردشكَرى ضمن تصحيل فرايند توسعه روستايى از طريق

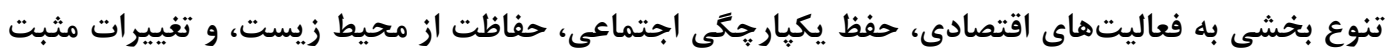

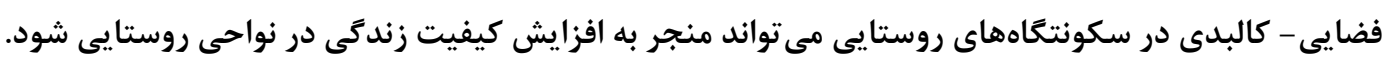

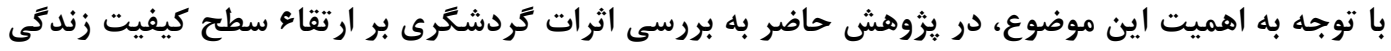

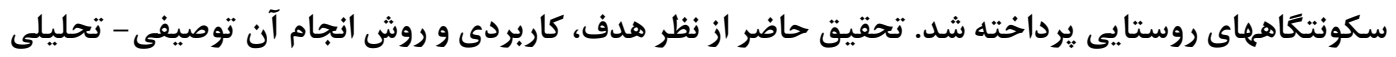

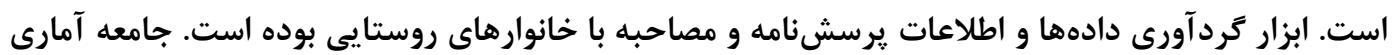

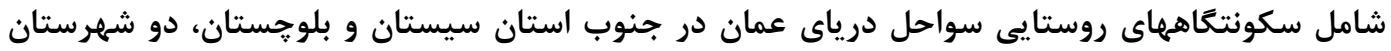
ساحلى كنارك و جابهار مي باشد (NADA

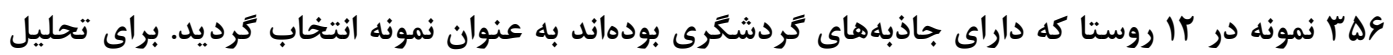

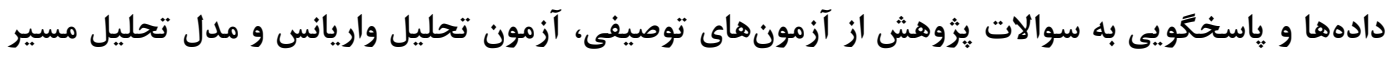

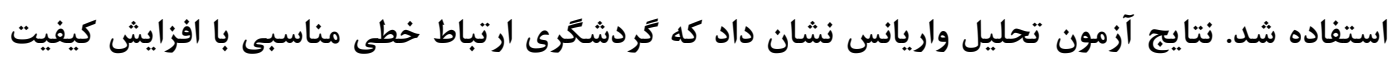

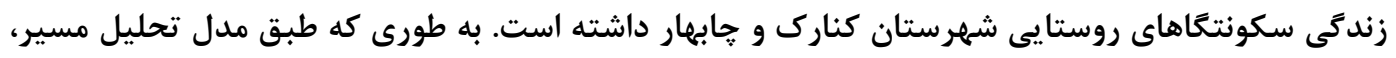
كردشكرى روستايى اثرات مختلف و مطلوبى بر شاخصهاى اقتصادى، اجتماعى، محيطى و كالبدى - فضايى

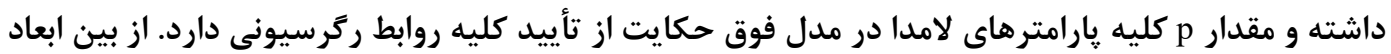

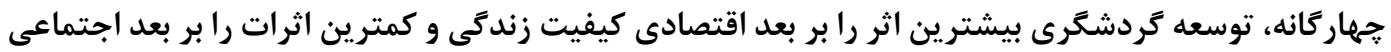
كيفيت زندكى در سكونتكاههاى روستاهاى داشته است.

كليد وازَٔان: كردشكرى، گردشكرى روستايى، كيفيت زندگى، سكونتكاههاى ساحلى، جنوب سيستان و بلوجستان. 


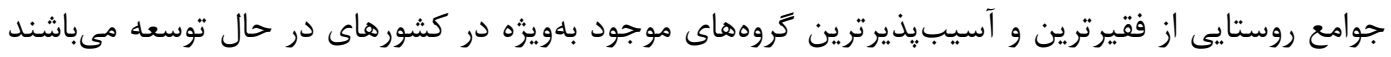

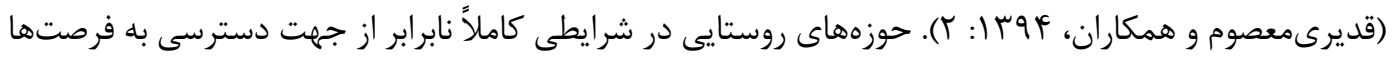

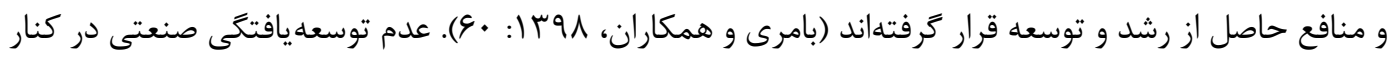

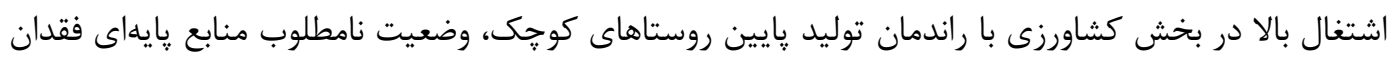

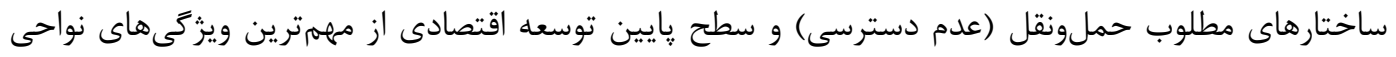

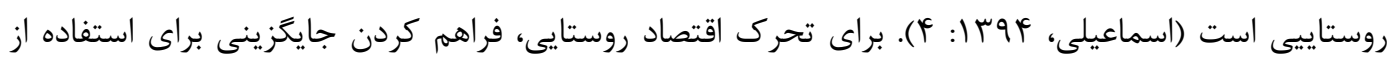

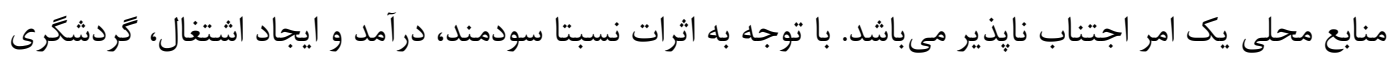

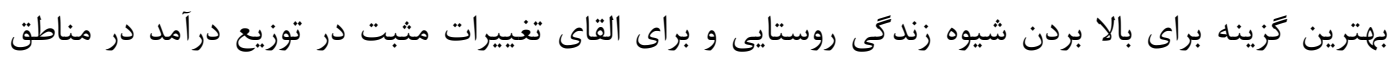

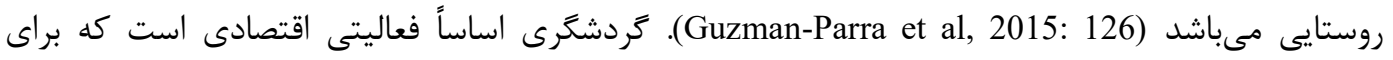

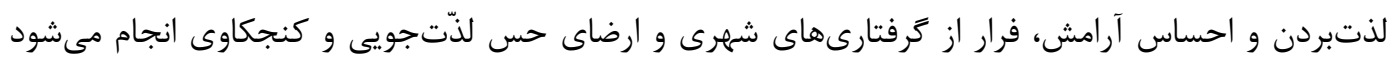

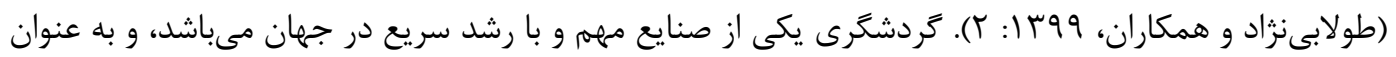

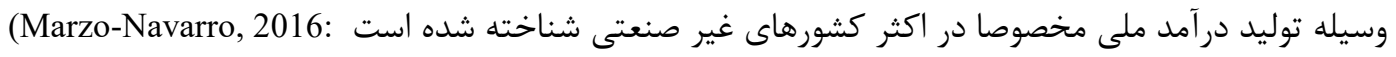

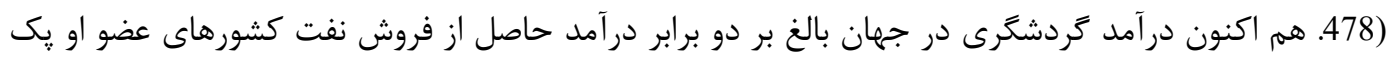

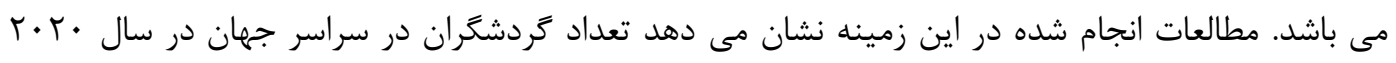

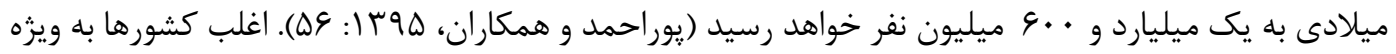

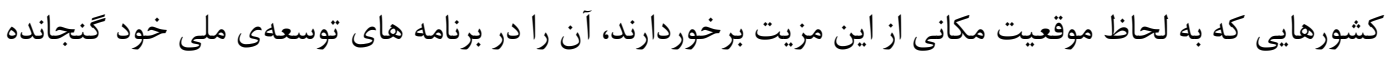

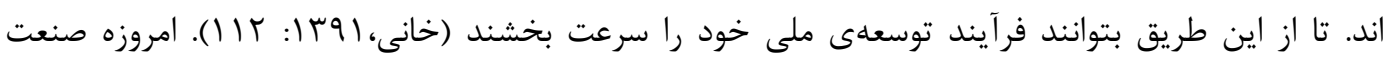
كردشكرى تبديل به يك ابزار و اولويت براى برنامهريزى روستايى شده است (Chim-Miki et al, 2020: 132) و

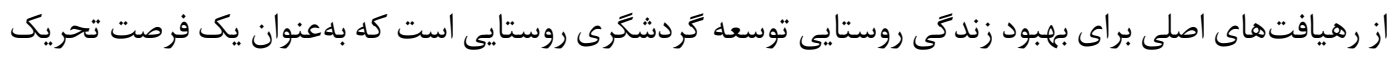

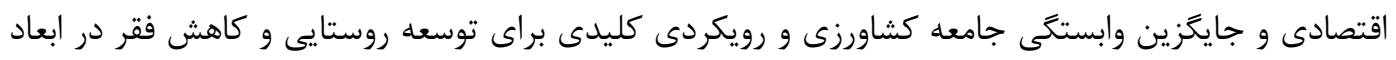

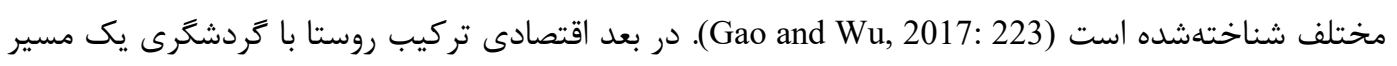

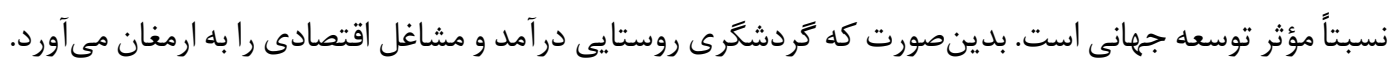

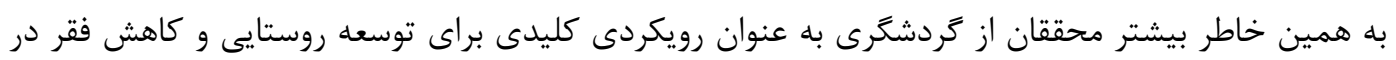

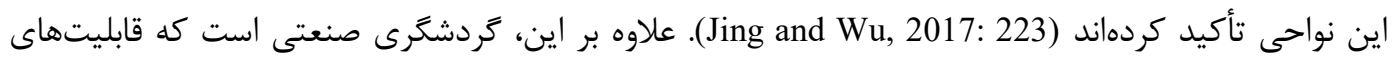

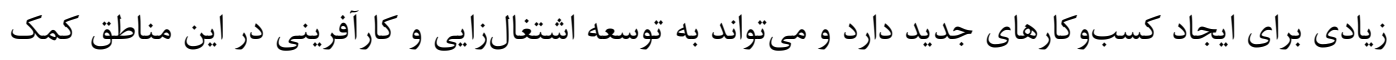

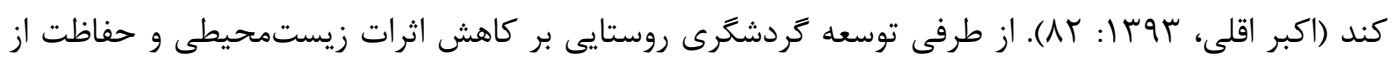

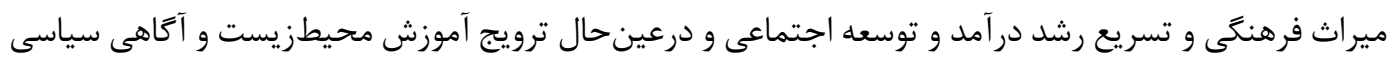

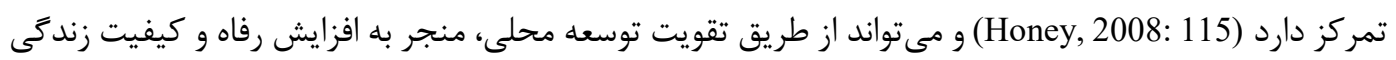

روستاييان شود (Rasoolimanesh et al, 2017:149).

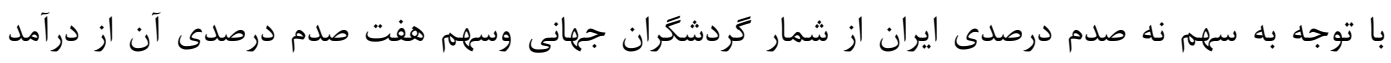

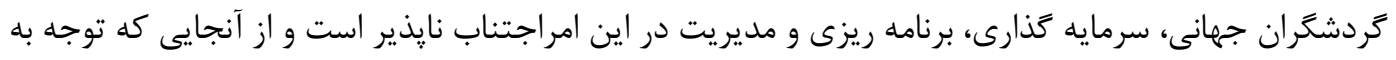


اين صنعت در ايران نيز اثرات مثبت بسيارى بر اقتصاد ملى به ويزه اقتصاد روستاهاى گردشكرى به دنبال خواهد

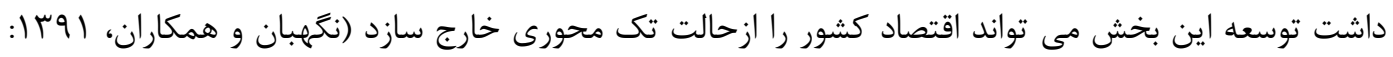

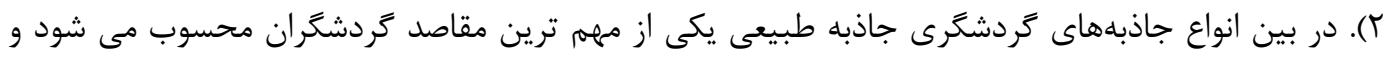

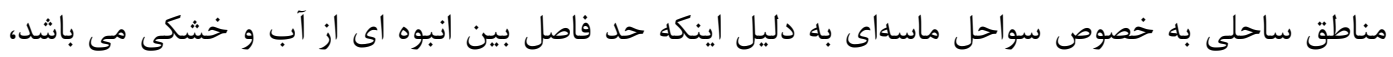

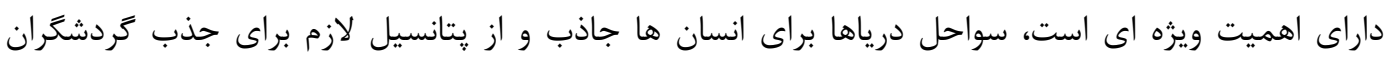

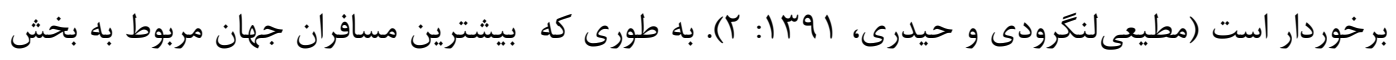

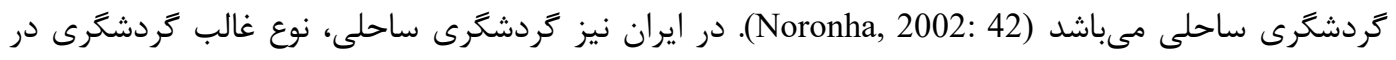

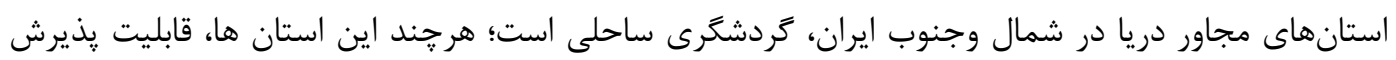

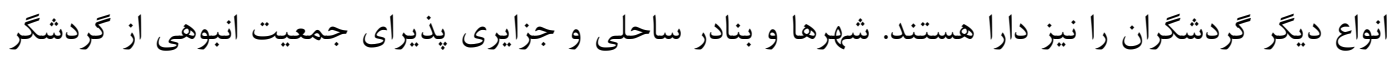

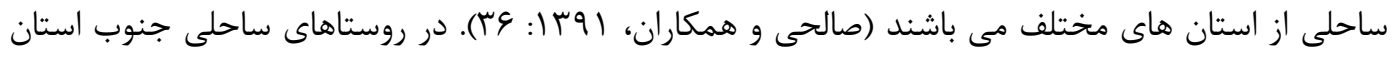

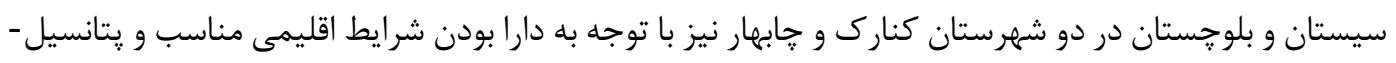

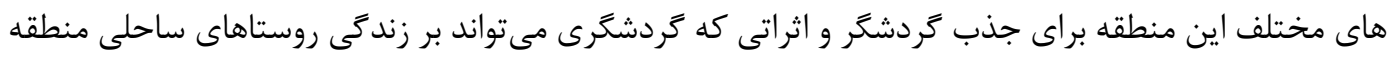

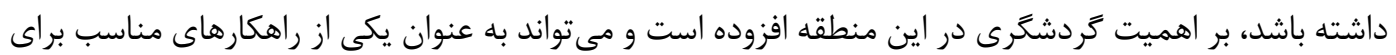

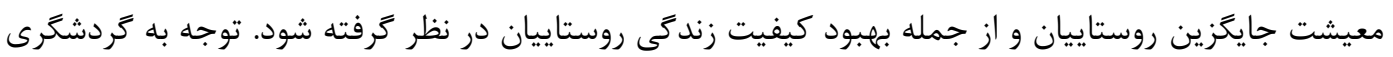

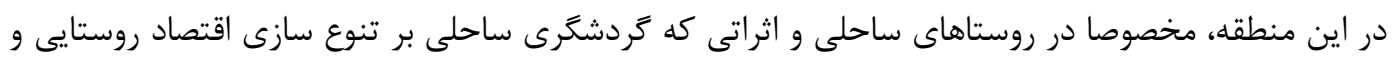

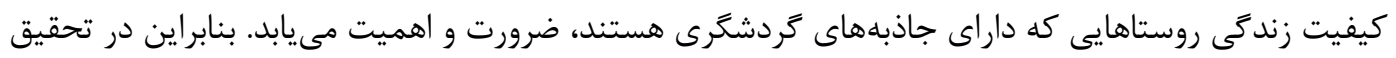

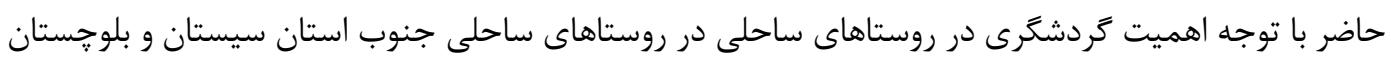

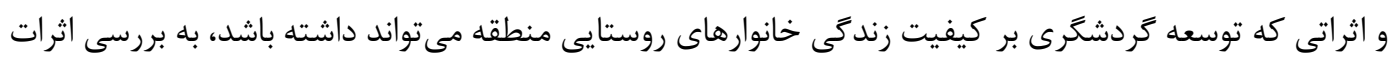

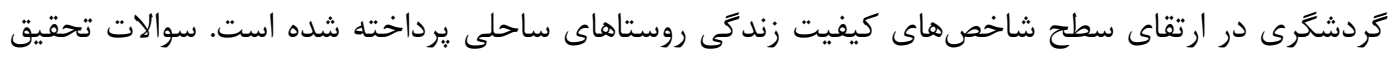

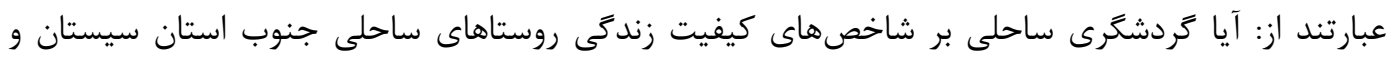

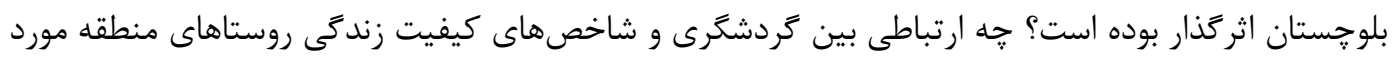

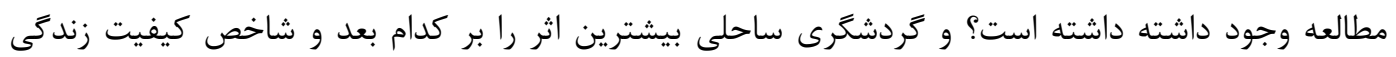
روستايى در روستاهاى منطقه مورد مطالعه داشته است؟

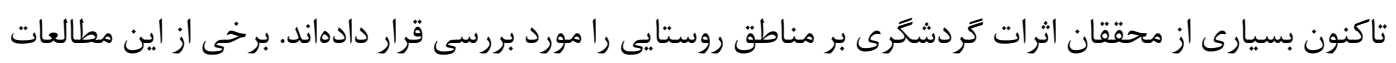

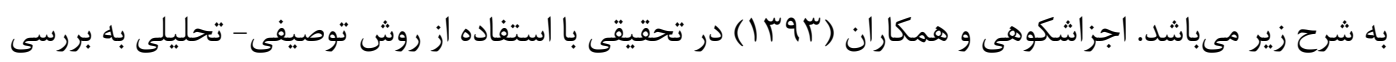

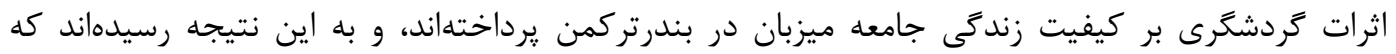

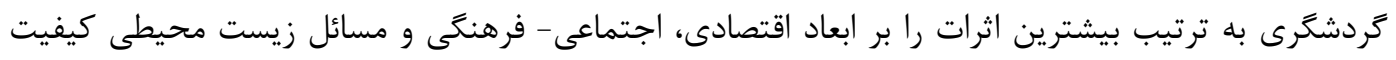

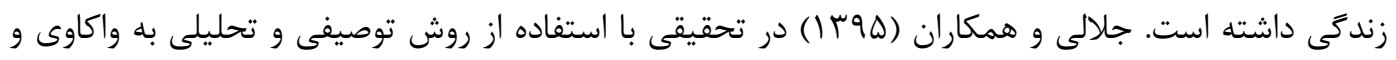

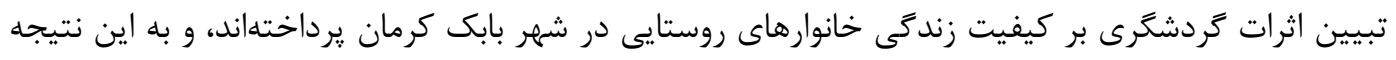

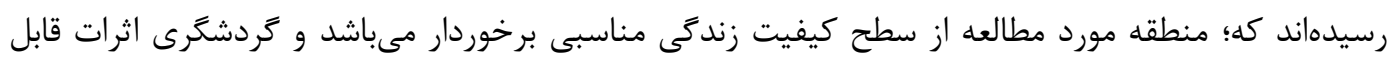

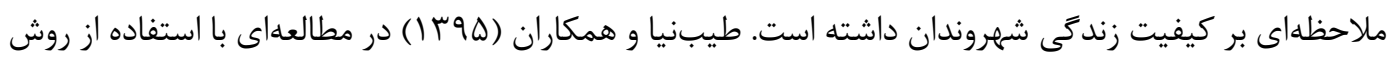

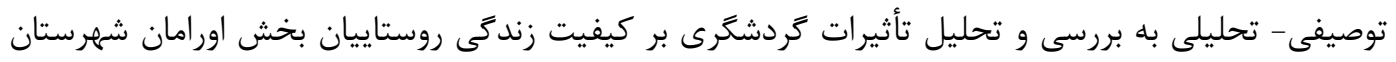


سروآباد برداختهاند، و به اين نتيجه رسيدهاند كه توسعه كردشكرى موجب بهبود سطح كيفيت زندكى روستاييان

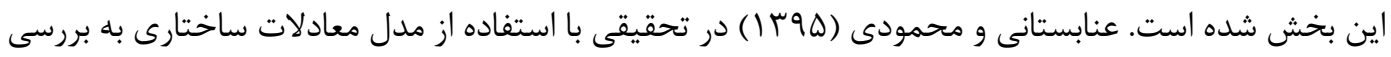

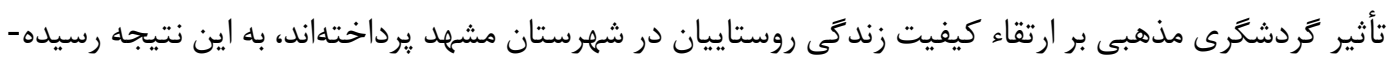

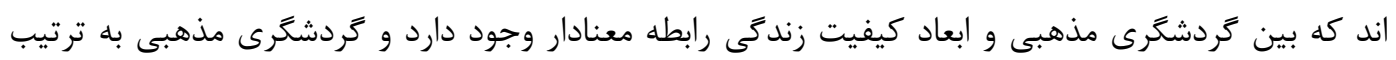

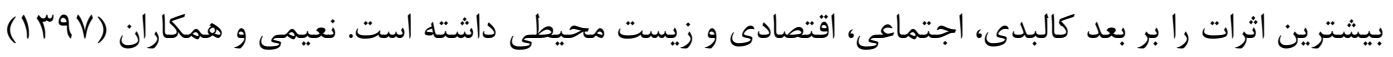

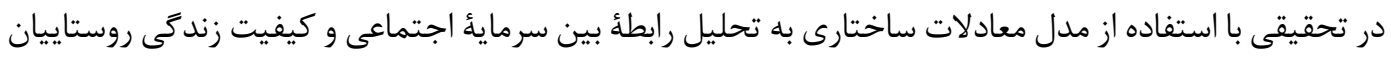

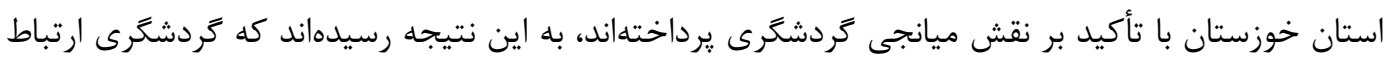

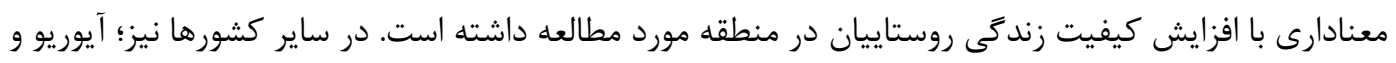

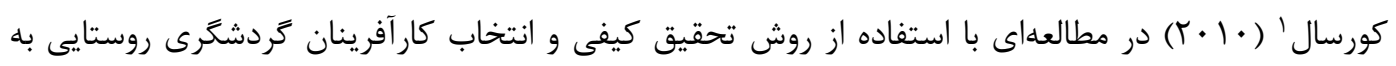

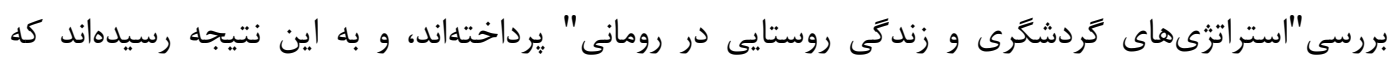

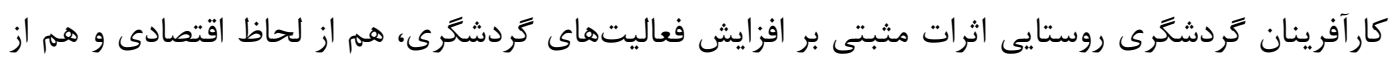

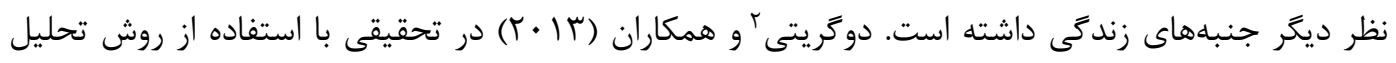

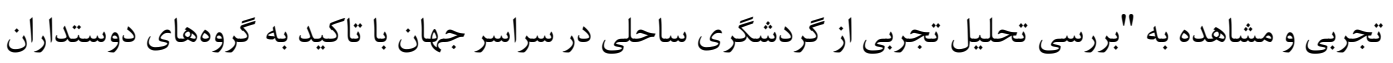

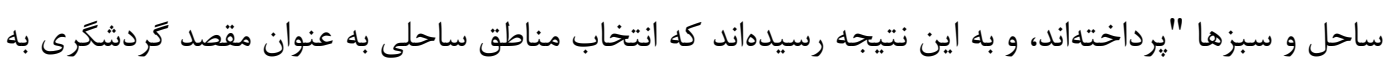

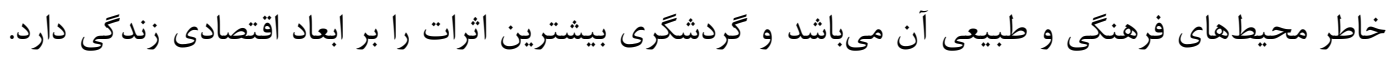

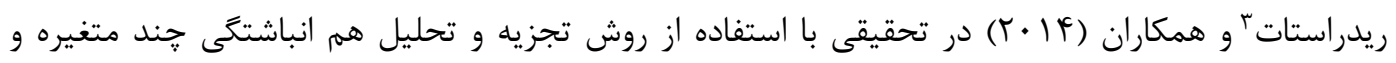

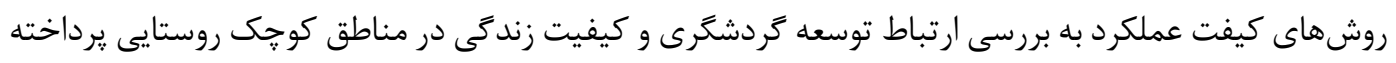

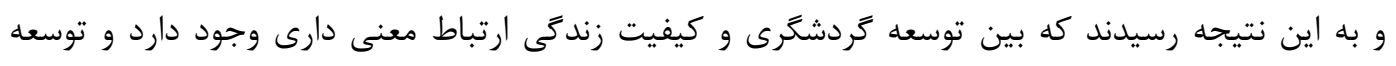

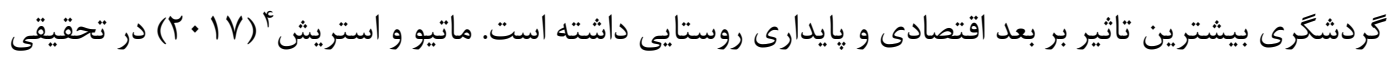

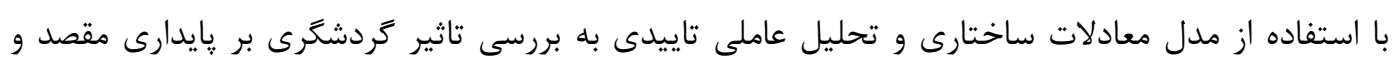

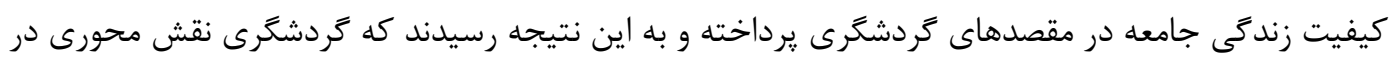

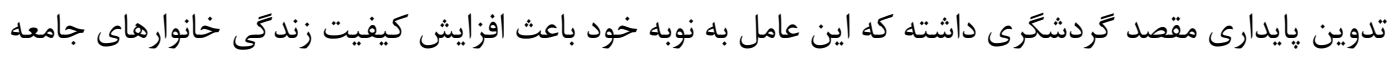

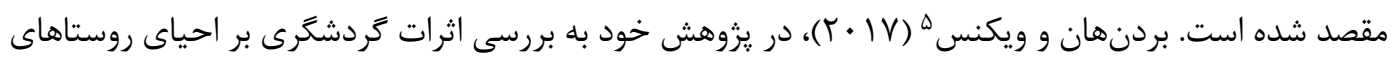

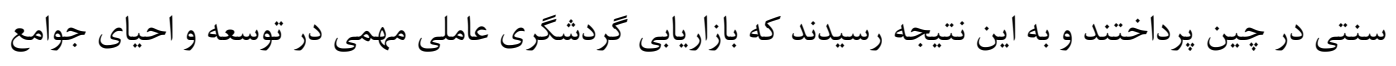

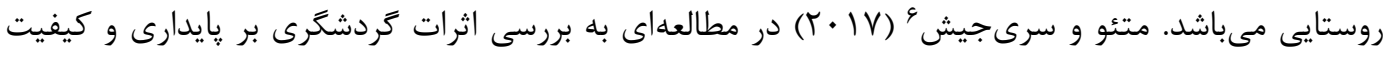

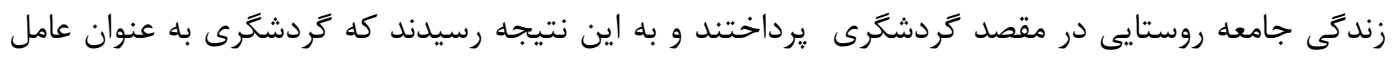

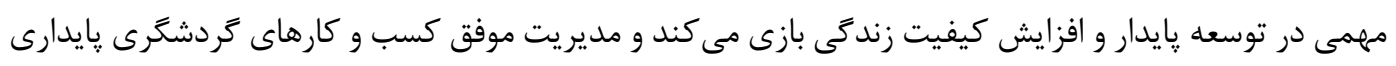




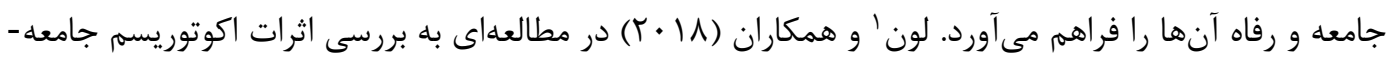

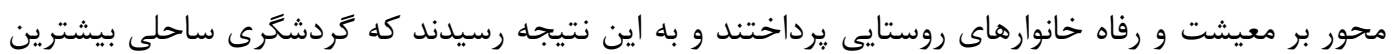
اثر را بر درآمد و تحرك اقتصادى خانوارهاى روستايى داشته است.

\section{مبانى نظرى}

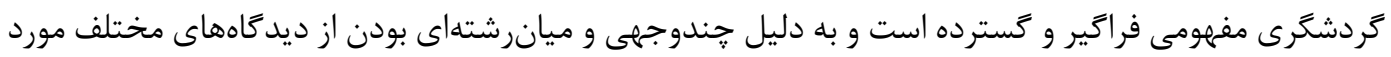

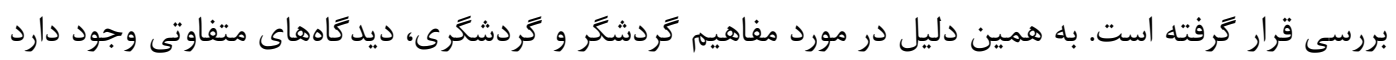

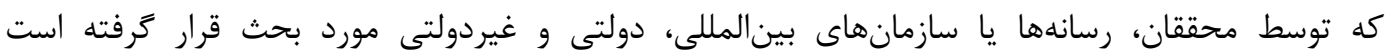

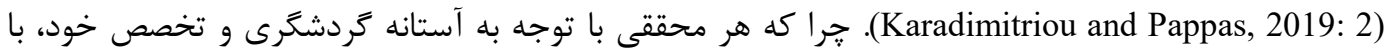

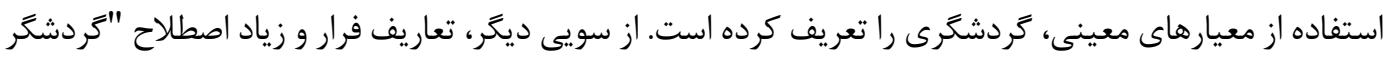

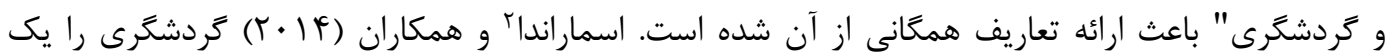

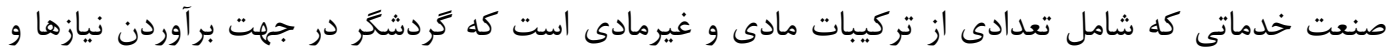

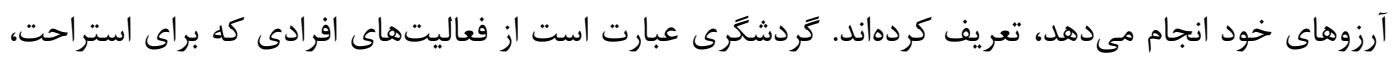

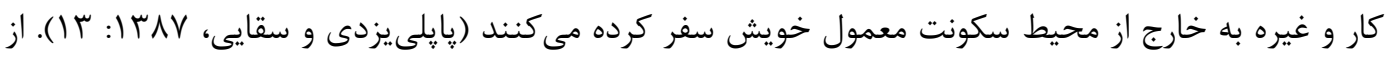

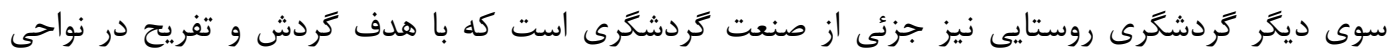

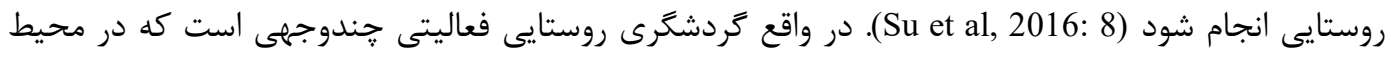

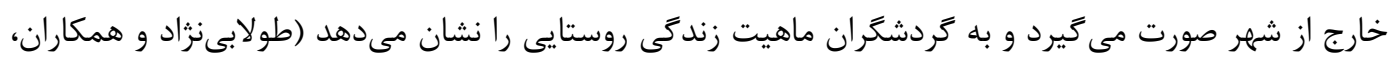

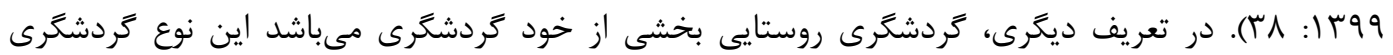

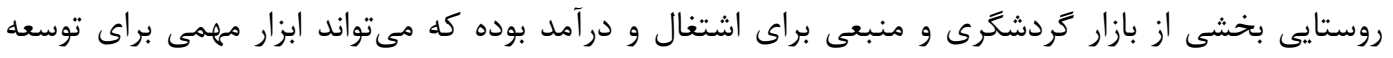

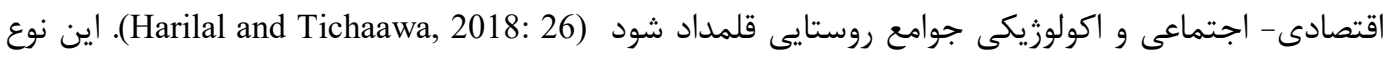

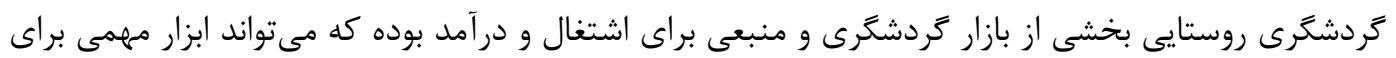

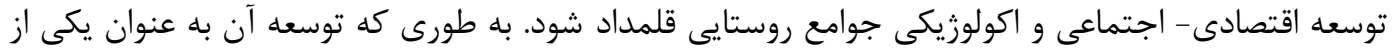

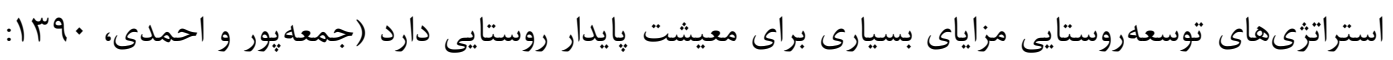

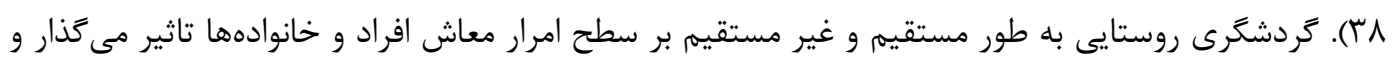

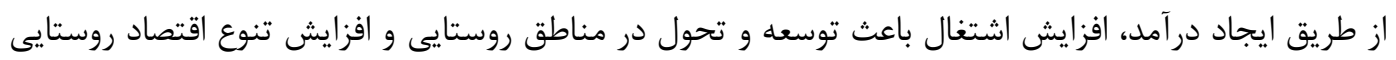

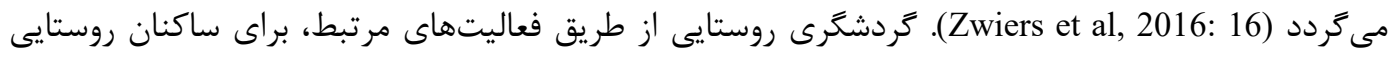

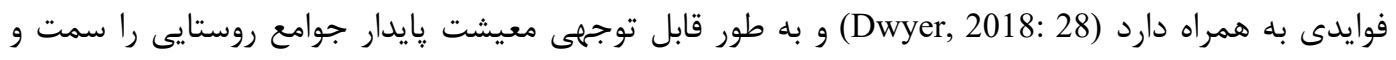
سوى داده است (Gentle and Maraseni, 2012: 24). بدين صورت كه كردشكرى روستايى درآمد و مشاغل

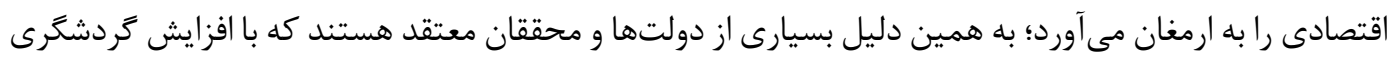

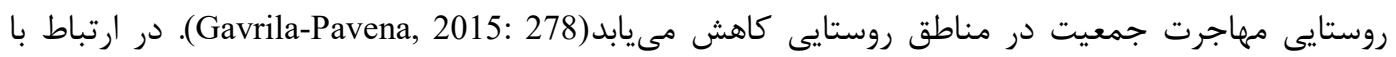

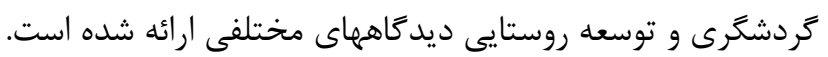


ديدگاه اول: گردشكَى بلمثابه راهبردى براى توسعه روستايى؛ در اين ديدگاه مفهوم گردشكرى روستايى و

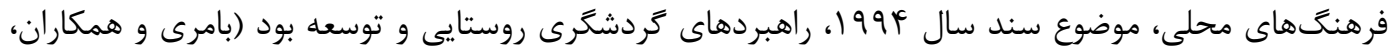

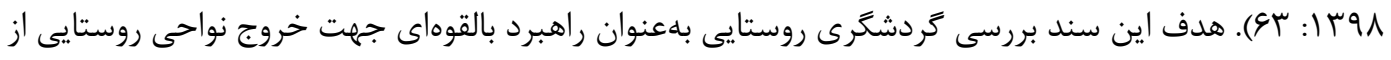

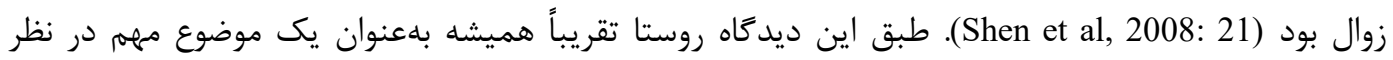

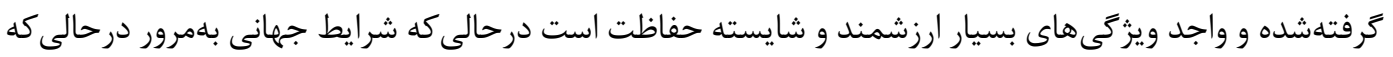

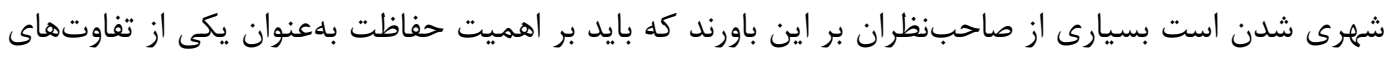

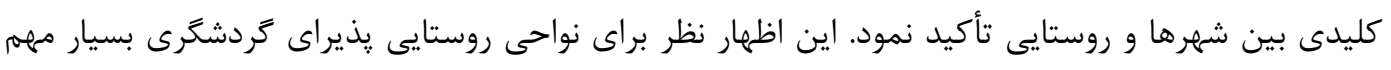

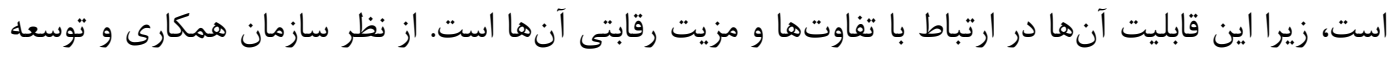

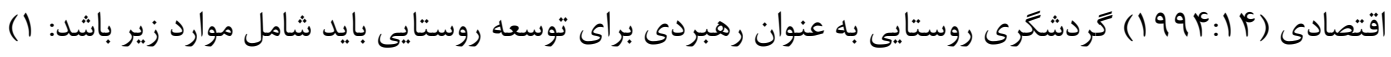

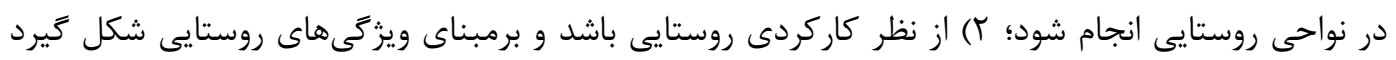

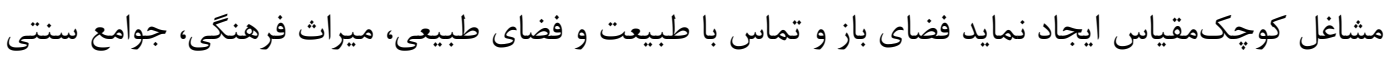

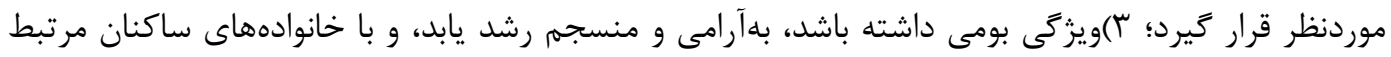

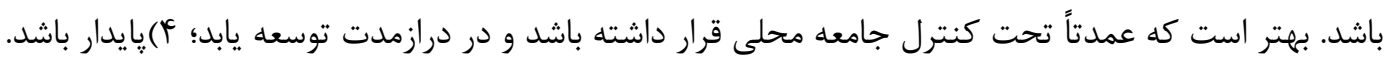

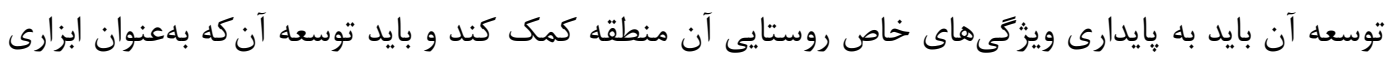

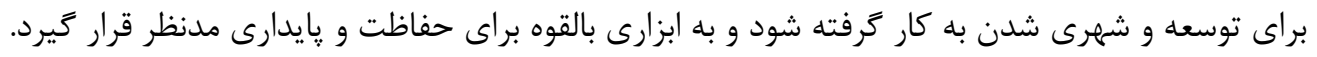

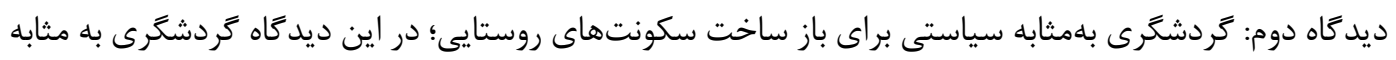

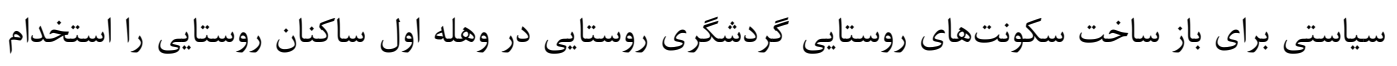

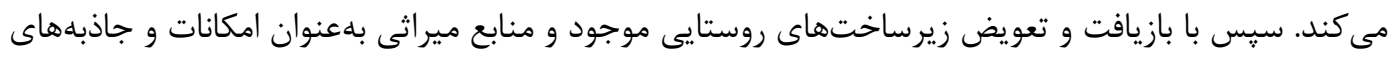

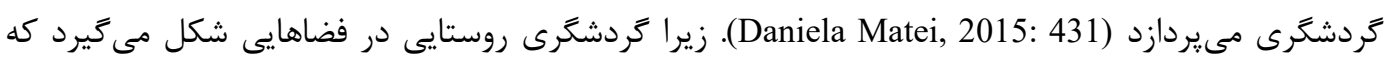

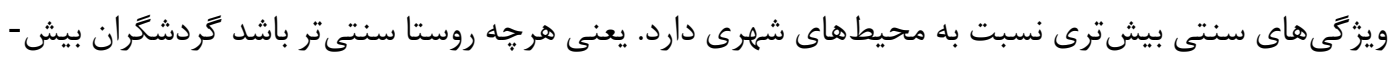

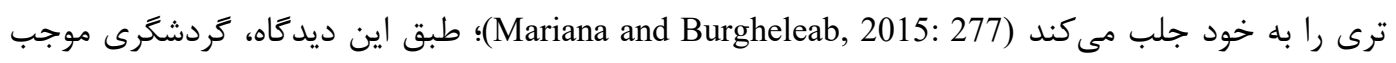

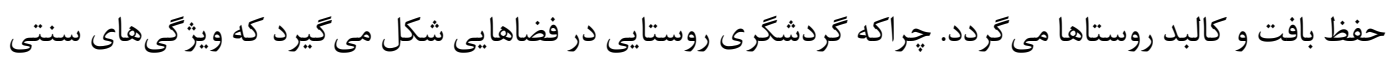

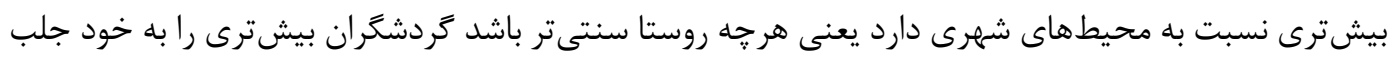

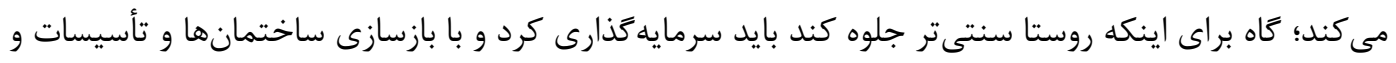

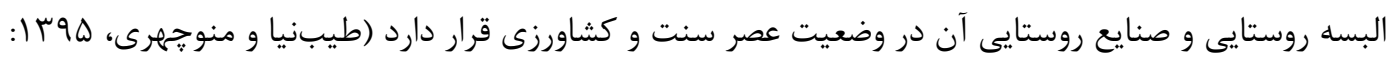

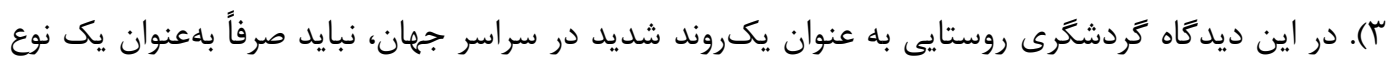

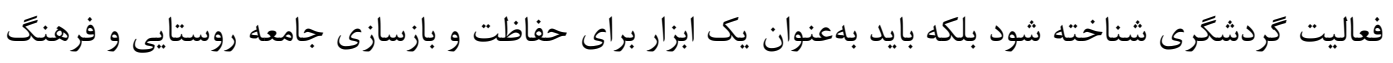

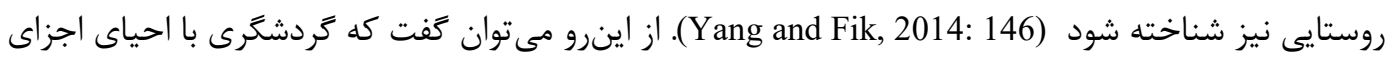

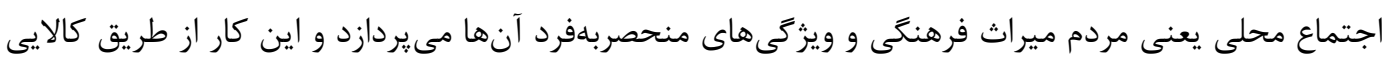

شدن فرهنَ صورت مى يذيرد (George, 2009: 28).

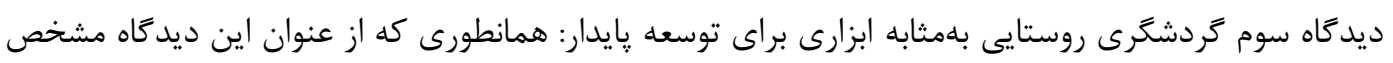

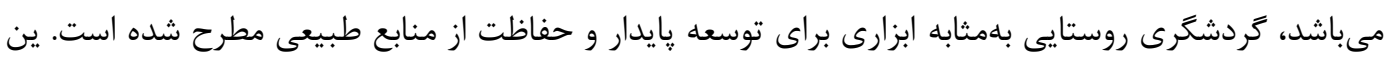




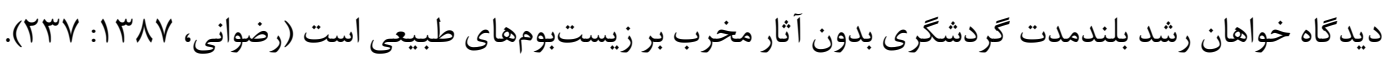

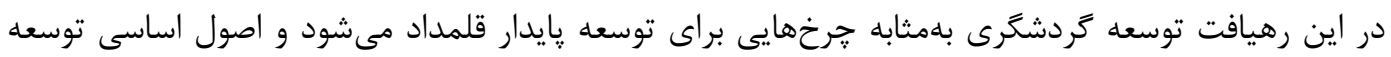

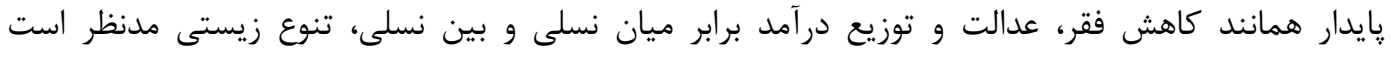

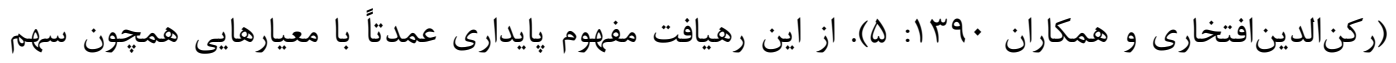

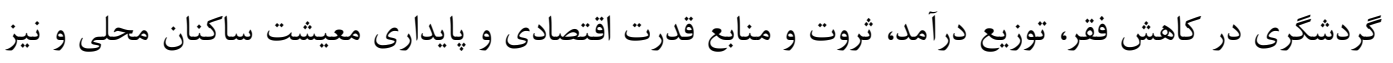

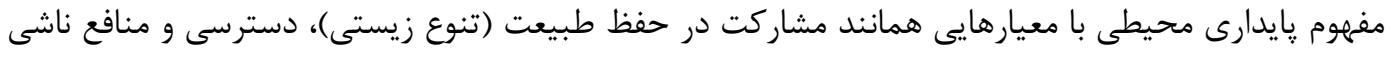

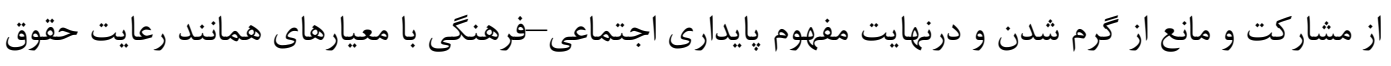

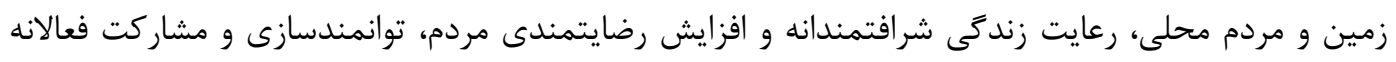

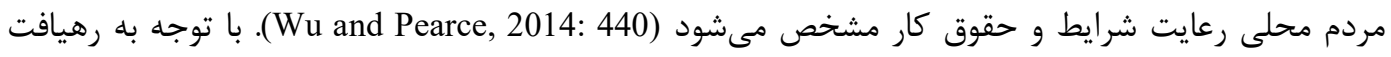

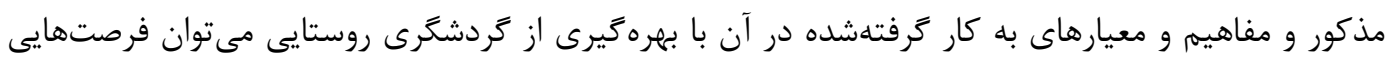

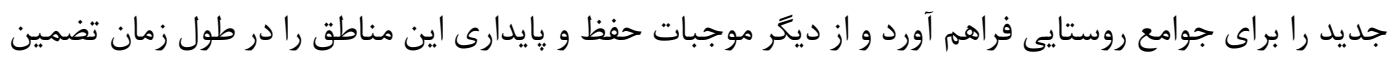

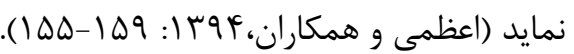

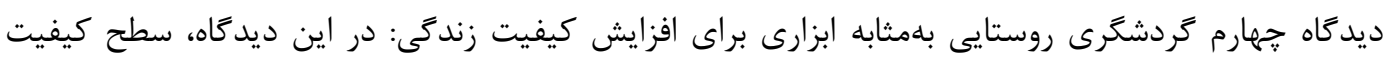

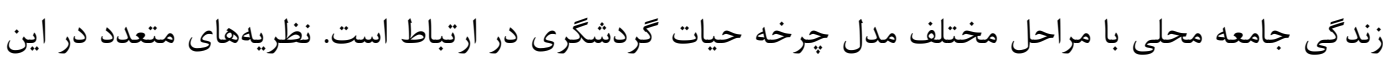

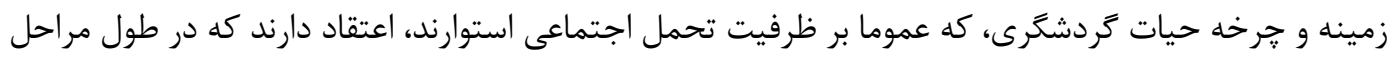

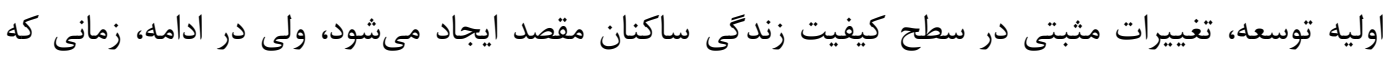

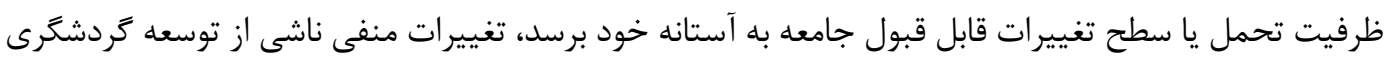

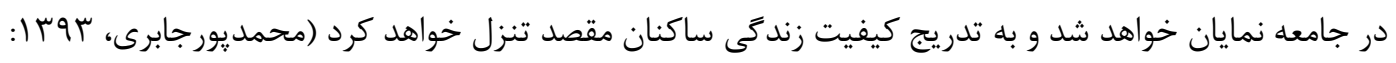

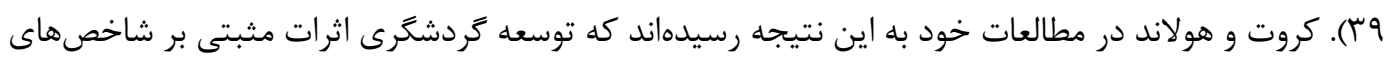

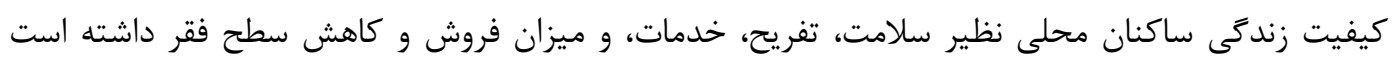

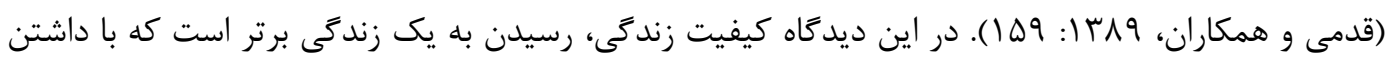

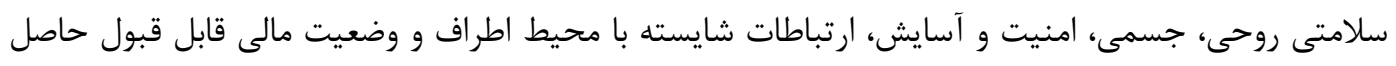

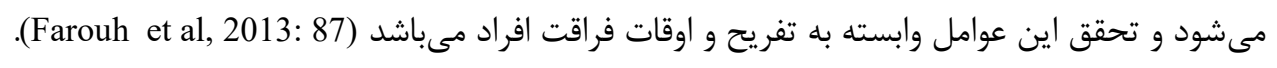

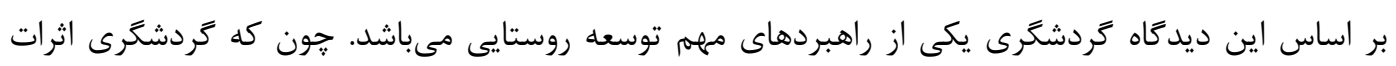

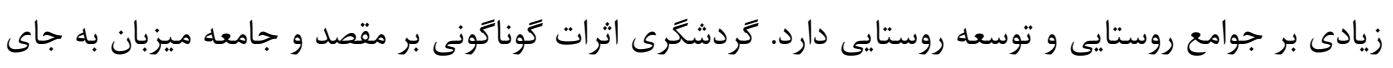

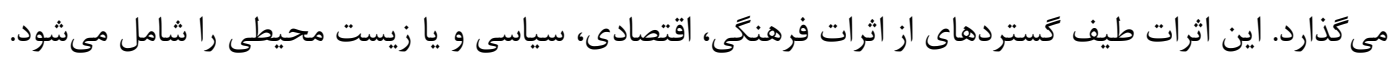

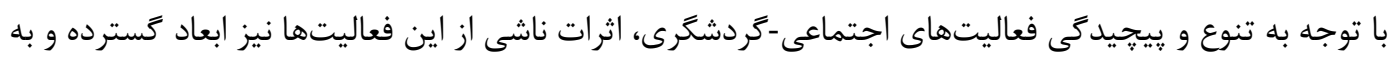

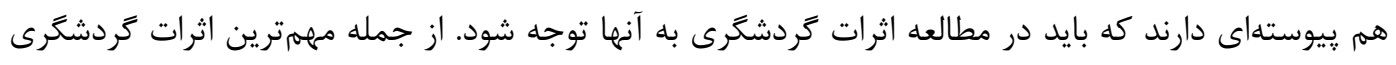

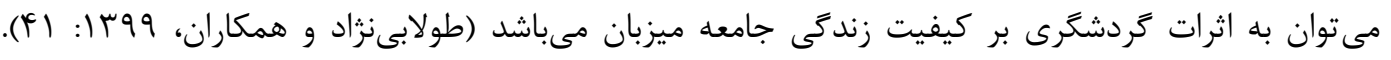

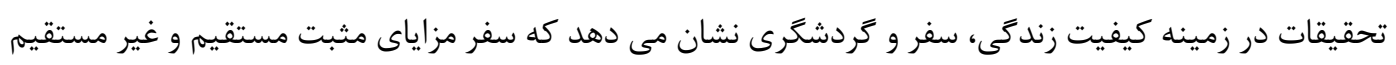

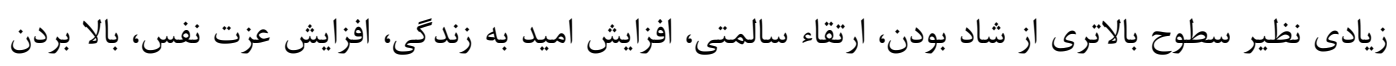

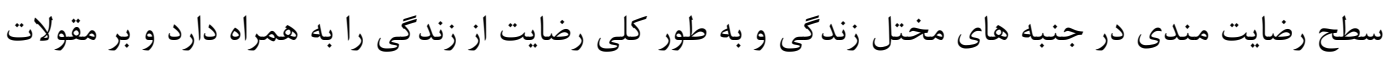


مرتب با توانايى كردشكرى در ارتقاء و كاهش كيفيت زندكى ساكنان جوامع ميزبان تاكيد دارد (شكوهى و

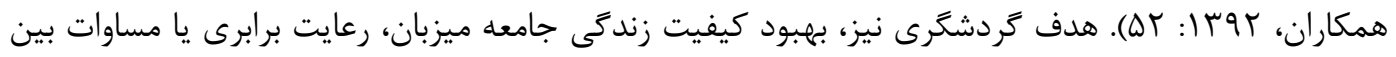

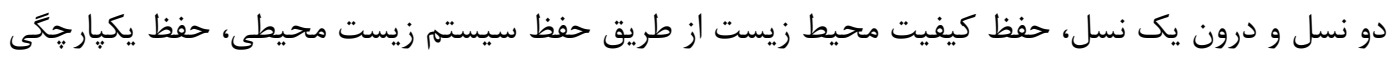

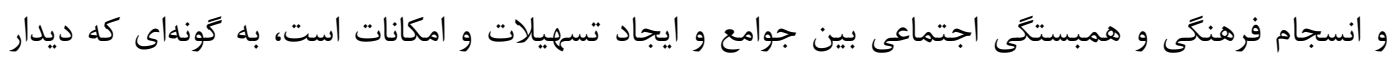
كنندكان بتوانند تجربههاى ارزشمندى كسب كنند (ابراهيمزاده و آقاسىزاده،

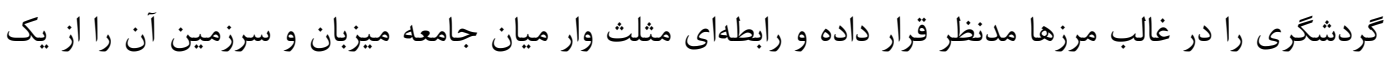

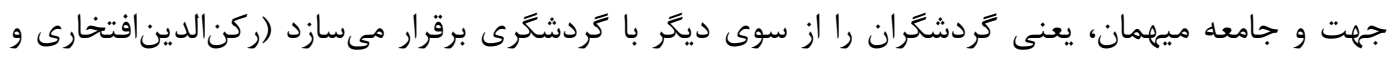

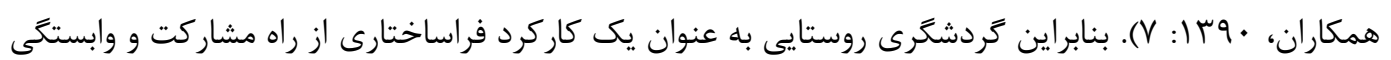

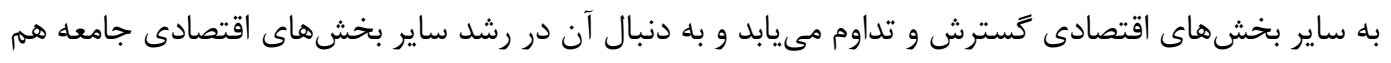

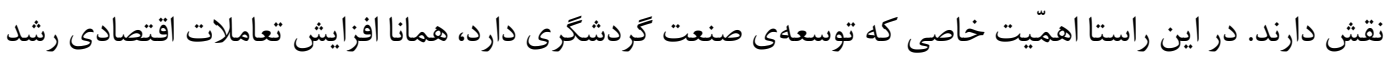

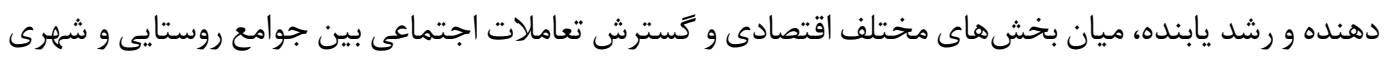

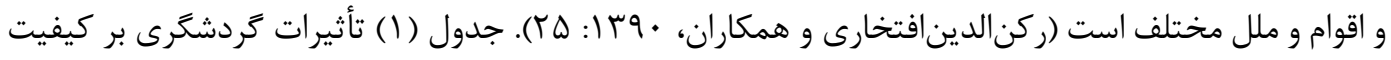

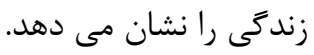

جدول (1): اثرات كردشگرى بر كيفيت زندگى

\begin{tabular}{|c|c|c|}
\hline 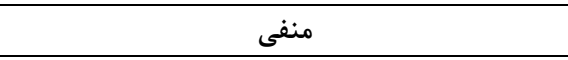 & مثبت & تأثيرات \\
\hline افزايش قيمت در طى رويدادهاى خاص، ظهور رانت خوارى & يويايى اقتصاد، ايجاد اشتغال و استخدام & 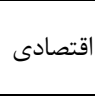 \\
\hline آسيب هاى زيست محيطى، ازدحام & ساخت امكانات جديد، بهبود زيرساخت هاى محلى. & فيزيكى \\
\hline 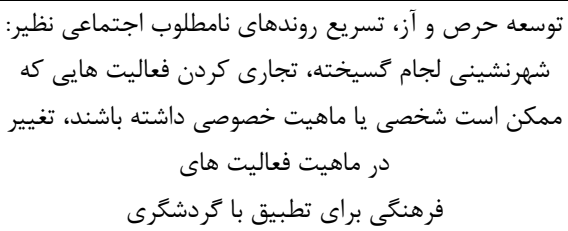 & 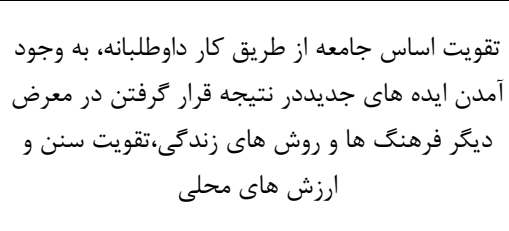 & فرهنكى \\
\hline
\end{tabular}

منبع: عنابستانى و محمودى، له9 1: 1 +.

در شكل ( (1) نيز بر اساس اثرات كردشكرى بر شاخصهاى كيفيت زندكى سكونتخاههاى روستايى و با توجه به

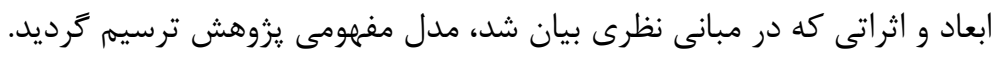




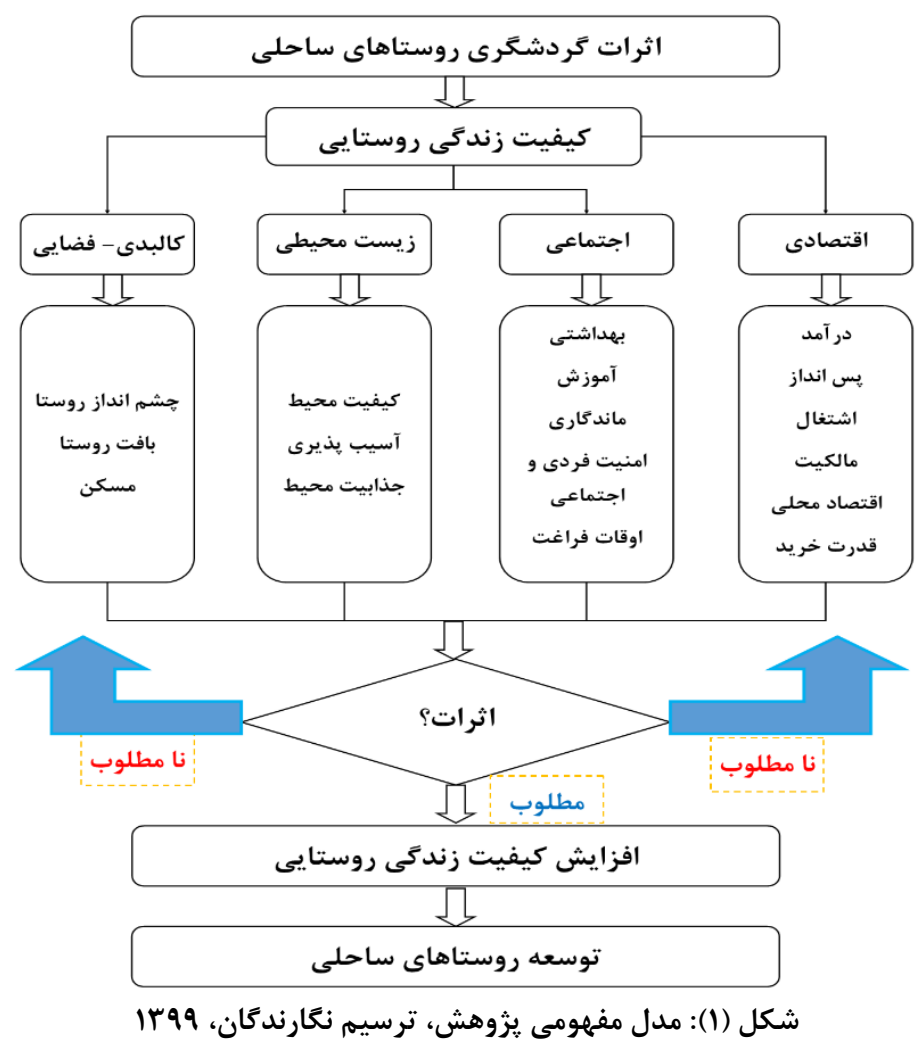

\section{روش تحقيق منطقه مورد مطالعه}

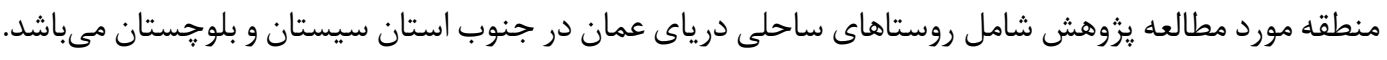

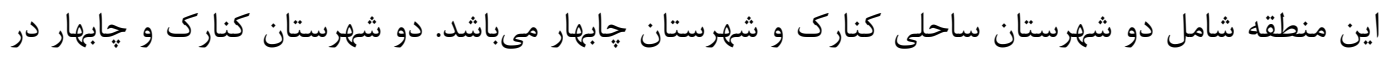

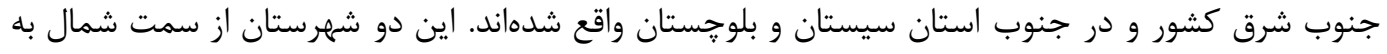

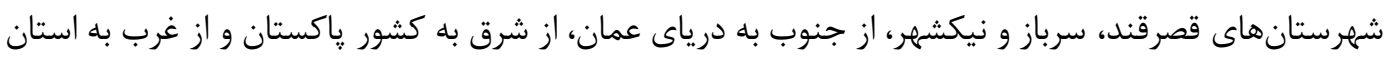

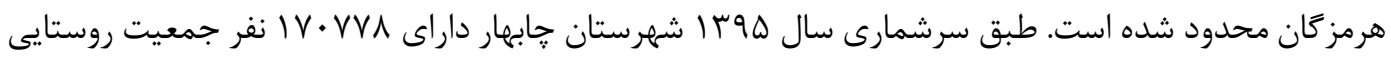

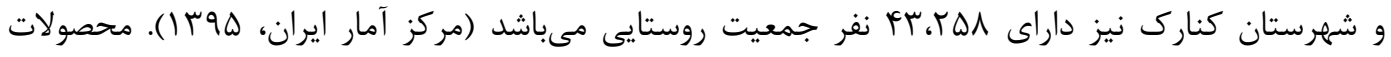

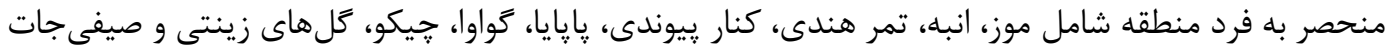

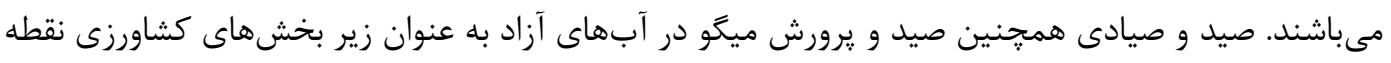

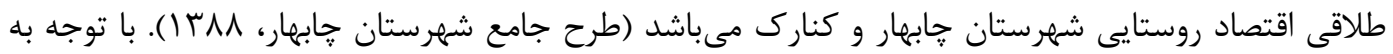

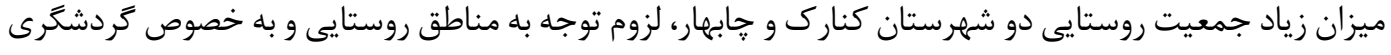

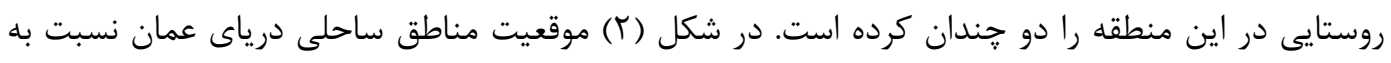
استان، و شهرستانهاى ديكر آورده شده است. 


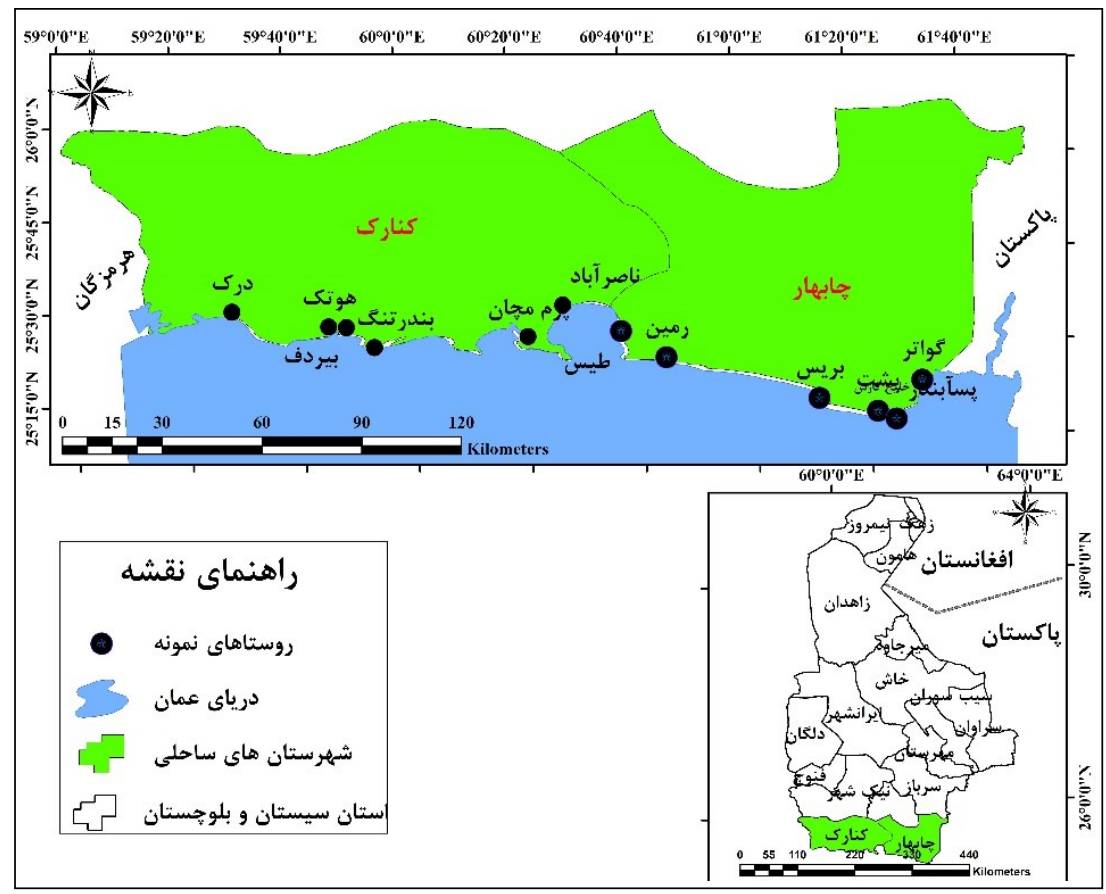

شكل (r): نقشه منطقه مورد مطالعه و روستاهاى نمونه

داده و روش كار

تحقيق حاضر از نظر هدف، كاربردى و روش انجام آن توصيفى- تحليلى مىباشد. مطالعات نظر يهاى با استفاده از

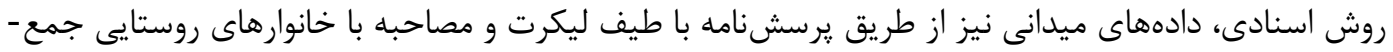

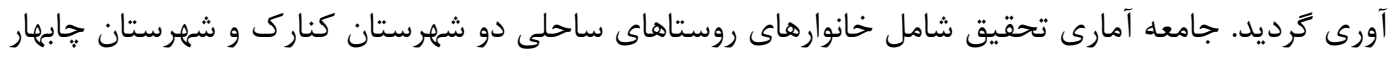

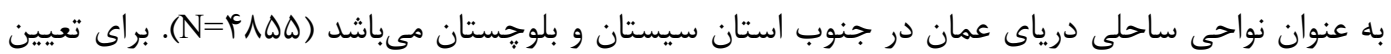

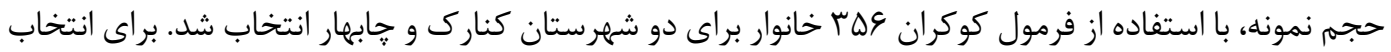

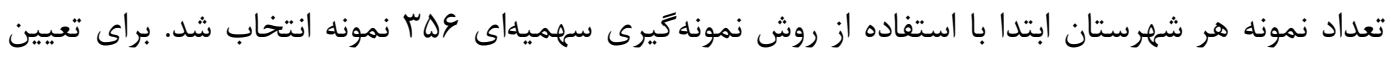
حجم نمونه هر شهرستان نيز از فرمول تعيين حجم نسبيت (با توجه به تعداد خانوار هر شهرستان) استفاده شدها

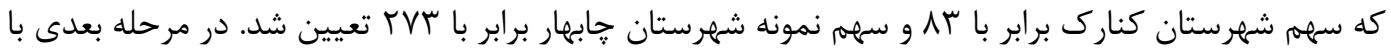

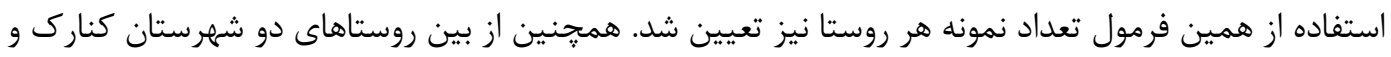

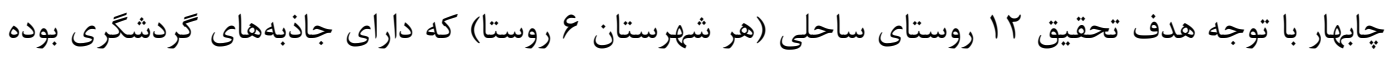

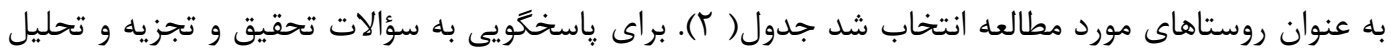

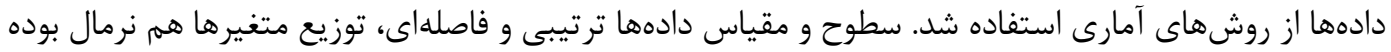

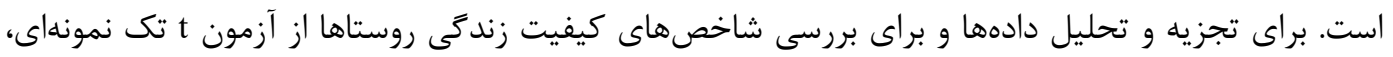

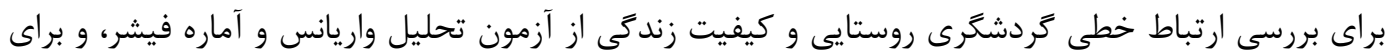

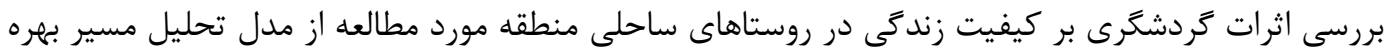




\begin{tabular}{|c|c|c|c|c|}
\hline تعداد نمونه & جمعيت روستا & تعداد خانوار & نام روستا & شهرستان \\
\hline$\wedge$ & frq & $1 . r$ & درى & \multirow{6}{*}{ كنارى } \\
\hline 11 & $1 \cdot r$. & TFF & ناصراباد & \\
\hline TQ & $10 \cdot 4$ & TF & بندرتنگ & \\
\hline V & rar & $1 . r$ & هوتك & \\
\hline 4 & res & 11 & بيردف & \\
\hline 19 & 1119 & TET & يزم مجان & \\
\hline 9 & $9 M \Lambda$ & $|r|$ & شهرك مسكونى گواتر & \multirow{6}{*}{ جابهار } \\
\hline ir & $\Lambda \Delta \Lambda$ & 191 & يشت & \\
\hline 91 & rATl & $\Lambda \mu \Delta$ & رمين & \\
\hline 19 & 1.94 & TIF & يسابندر & \\
\hline \& & FFMA & N\& & بريس & \\
\hline $11 r$ & GHYA & IDTE & تيس & \\
\hline$r \Delta \varphi$ & $T r \cdot I V$ & $\uparrow \wedge \Delta \Delta$ & \multicolumn{2}{|l|}{ جمع كل } \\
\hline
\end{tabular}

روايى يرسشنامه با استفاده از روايى محتوا سنجيده و مورد تاييد قرار كرفت، كه توسط افرادى متخصص در

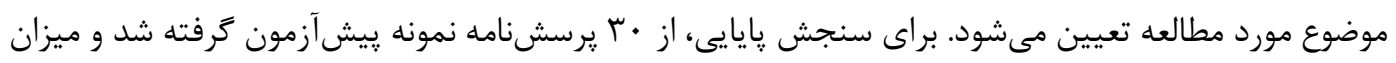

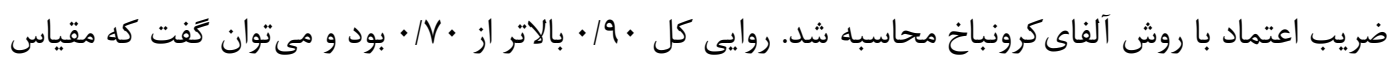

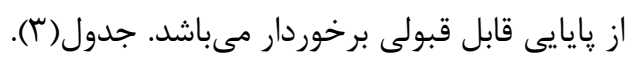

جدول (r). ميزان آلفاى محاسبه شده براى هر يك از ابعاد رفاه خانوارها

\begin{tabular}{|c|c|c|c|c|}
\hline ميزان آلفاى كرونباخ & شماره تويه & تعداد تويه & تعداد شاخص & ابعاد رفاه \\
\hline.$/ 94$ & $r t-1$ & tr & $\Delta$ & اقتصادى \\
\hline$\cdot / \mathrm{AV}$ & (1) & 19 & $\Delta$ & اجتماعى \\
\hline$\cdot 1 / 9$ & DI $-F T$ & 1. & r & زيست محيطى \\
\hline$\cdot / 9 \mathrm{~F}$ & $99-\Delta T$ & 10 & $r$ & كالبدى- فضايى \\
\hline .19. & $99-1$ & 49 & 19 & جمع \\
\hline
\end{tabular}

نتايج

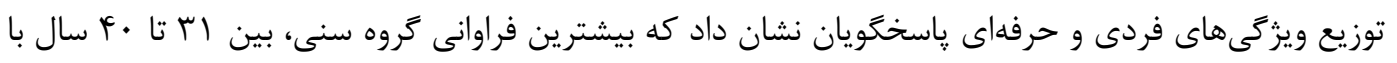

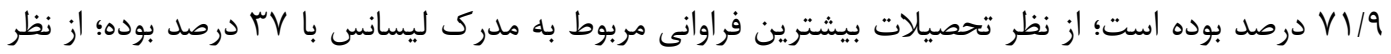

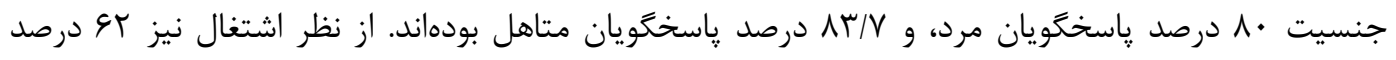

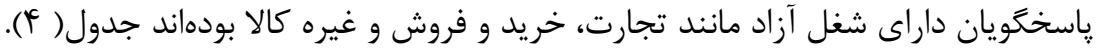




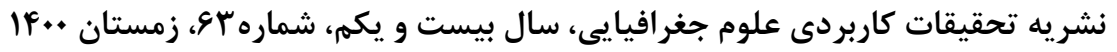

\begin{tabular}{|c|c|c|c|}
\hline درصد & تعداد & بيشترين پاسخگو & مشخصات پاسخ دهنده \\
\hline$V 1 / 9$ & $r \Delta \varphi$ & بين اس تا • ب سال & سن \\
\hline $\mathrm{rV} / \cdot$ & ITt & 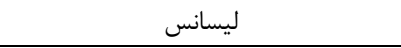 & 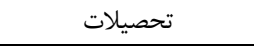 \\
\hline$\Lambda \cdot / r$ & rAS & 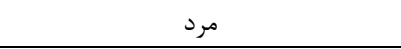 & جنسيت \\
\hline$\Lambda \mu / \vee$ & $r q \Lambda$ & 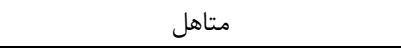 & تأهل \\
\hline GY/. & rt & آزاد ( تجارت، خريد و فروش كالا و غيره) & 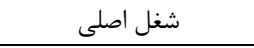 \\
\hline
\end{tabular}

\section{بر رسى شاخصهاى اقتصادى كيفيت زندكى}

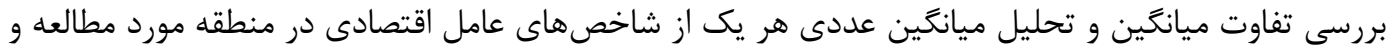

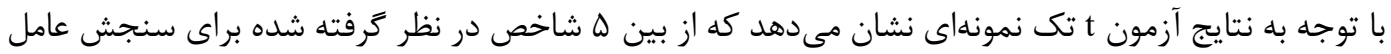

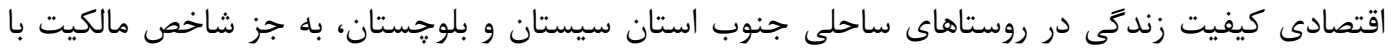

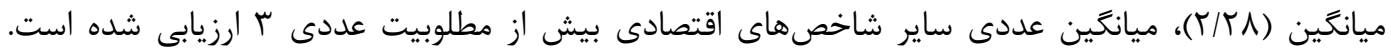

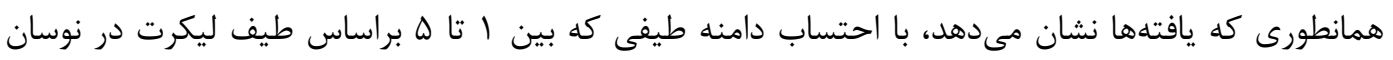

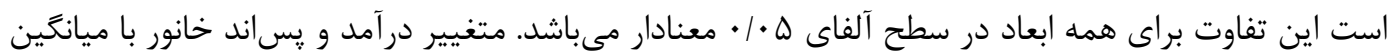

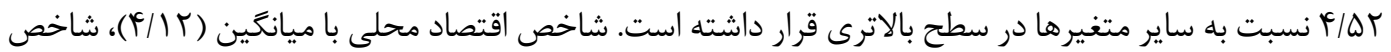

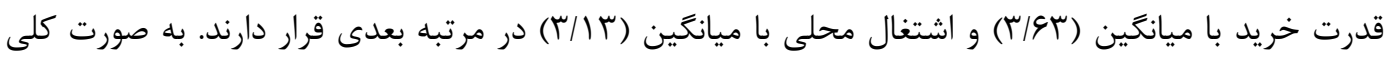

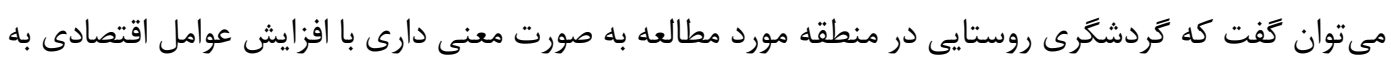

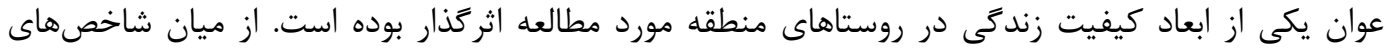

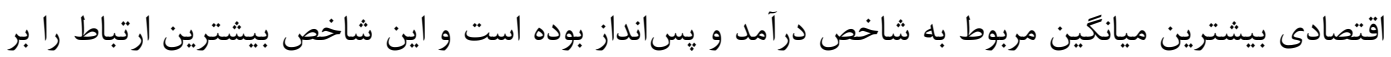

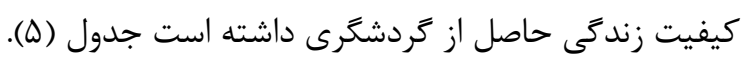

جدول (ه): شاخص هاى عامل اقتصادى كيفيت زندكى

\begin{tabular}{|c|c|c|c|c|c|c|}
\hline \multicolumn{7}{|c|}{ مطلوبيت عددى مورد آزمون = r } \\
\hline \multicolumn{2}{|c|}{ فاصله اطمينان هو درصد } & \multirow{2}{*}{ ميانگَين } & \multirow{2}{*}{ معنادارى } & \multirow{2}{*}{ 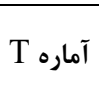 } & \multirow{2}{*}{ ميانغين } & \multirow{2}{*}{ شاخص } \\
\hline حد بالا & حد پايين & & & & & \\
\hline $1 / T 1$ & $\cdot|\Lambda|$ & $1 / \cdot 19$ & 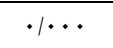 & $1 \% / 9 \Delta \Lambda$ & $F / I T$ & اقتصاد محلى \\
\hline .119 & .1 .9 & . & $\cdot / \cdots$ & D/TKT & r/l & اشتغال محلى \\
\hline$\cdot / 49$ & $.1 \cdot 4$ &.$/ T r$. & $\cdot / \cdots$ & $11 / \Lambda \Delta S$ & r/gr & قدرت خريد \\
\hline $1 / 91$ & $1 / \pi 1$ & $1 / 4 \wedge$ & $\cdot / \cdots$ & TI/TAT & F/QT & درآمد و يسانداز \\
\hline.$/ 1 Y$ & $.1 \cdot 1$ &.$|9|$. &.$/ \cdot r$ & $r / / 94$ & T/TA & مالكيت افراد \\
\hline
\end{tabular}

\section{بر رسى شاخصهاى اجتماعى كيفيت زندكى}

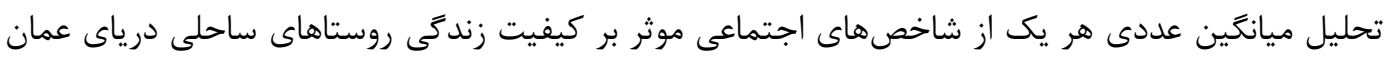

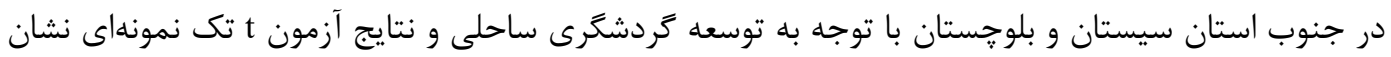

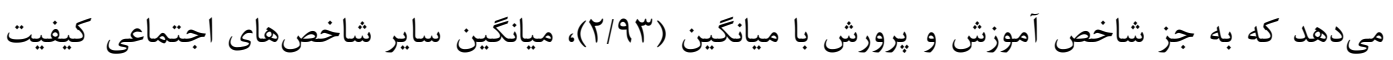

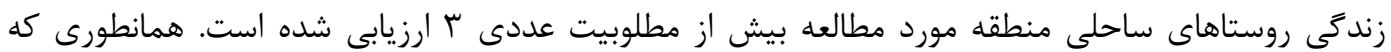


يافتههاى اين آزمون نشان مىدهد، با احتساب دامنه طيفى كه بين ا تا ها براساس طيف ليكرت در نوسان است

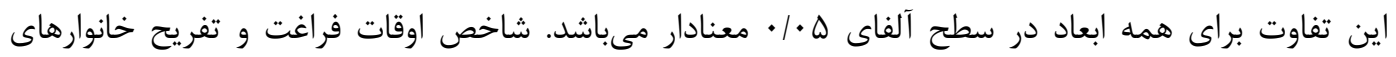

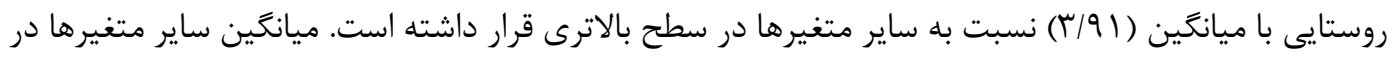

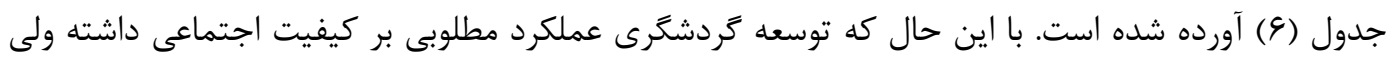
اين ميزان در سطح جندان بالايى نبوده است.

جدول (9): بررسى شاخصهاى عامل اجتماعى كيفيت زندتى

\begin{tabular}{|c|c|c|c|c|c|c|}
\hline \multicolumn{7}{|c|}{ مطلوبيت عددى مورد آزمون = } \\
\hline \multicolumn{2}{|c|}{ فاصله اطمينان ه9 درصد } & \multirow{2}{*}{ ميانغاوت } & \multirow{2}{*}{ معنادارى } & \multirow{2}{*}{ T Tاره T } & \multirow{2}{*}{ ميانگَين } & \multirow{2}{*}{ شاخص } \\
\hline حد بالا & حد پايين & & & & & \\
\hline$\cdot / \mathrm{V} \Lambda$ & 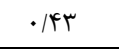 & $\cdot|\Delta \Delta \Delta|$ & $.1 \cdots$ & G|AT| & $r / l F$ & سطح ماندكارى \\
\hline$\cdot / T F$ & $.1 \cdot r$ & $\cdot 1 \cdot \Delta V$ & $.1 \cdot \mathrm{rr}$ & $r / \Delta / \Delta$ & r/9 & 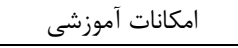 \\
\hline $1 / \cdot 9$ & .199 & $\cdot /$ / A 9 & $\cdot 1 \cdots$ & $1 \cdot 19 \Delta r$ & r/91 & اوقات فراغت \\
\hline$\cdot / \mathrm{VH}$ & $\cdot / T F$ & $\cdot / 4 \lambda F$ & $\cdot 1 \cdot$ & $\Delta / V 9 \Delta$ & $r / 1 \Lambda$ & امنيت فردى و اجتماعى \\
\hline - AT & $\cdot \pi$. & $\cdot \mid \Delta \Delta V$ & 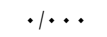 & G/KrT & $\Gamma / \Delta q$ & امكانات بهداشتى \\
\hline
\end{tabular}

\section{بررسى شاخص هاى زيست محيطى كيفيت زندكى}

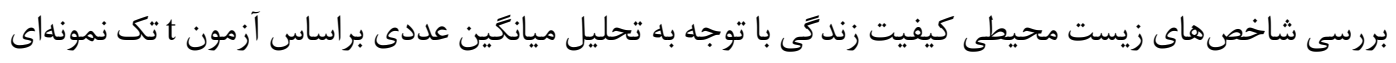

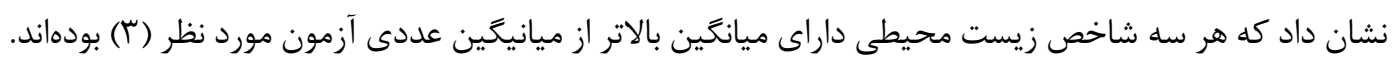

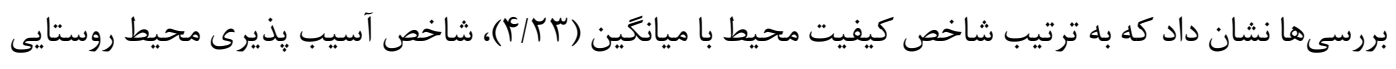

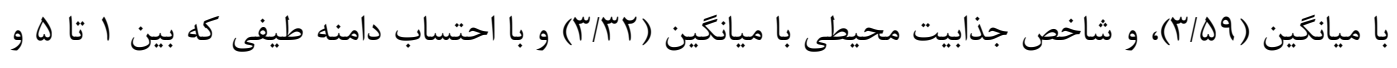

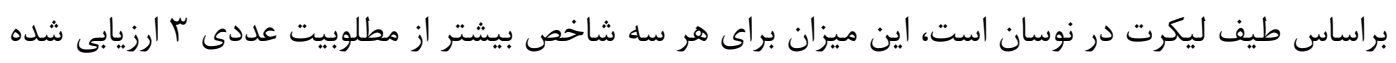

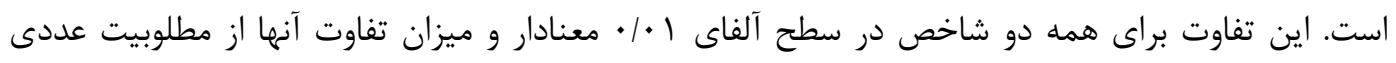

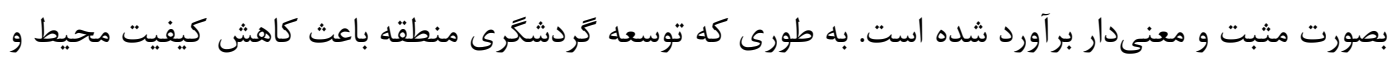

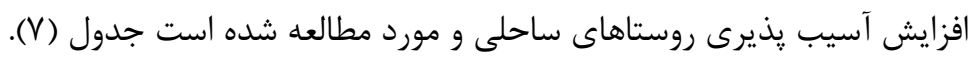

\begin{tabular}{|c|c|c|c|c|c|c|}
\hline \multicolumn{7}{|c|}{ r= مطلوبيت عددى مورد آزمون } \\
\hline \multicolumn{2}{|c|}{ فاصله اطمينان ه9 درصد } & \multirow{2}{*}{ ميانغين } & \multirow{2}{*}{ معنادارى } & \multirow{2}{*}{ T T T T } & \multirow{2}{*}{ ميانگين } & \multirow{2}{*}{ شاخص } \\
\hline حد بالا & حد يايين & & & & & \\
\hline - /At & $\cdot / r$ & $\cdot / \Delta \Delta V$ & $\cdot / \cdots$ & $\varepsilon / 1 \wedge \Delta$ & $r / \Delta 9$ & آسيب يذيرى \\
\hline $1 / \pi 9$ & $\cdot / 94$ & $1 / 1 \Delta 9$ & $\cdot / \cdots$ & $11 / F \Delta r$ & F/Tr & كيفيت محيط \\
\hline$\cdot / \mathrm{VA}$ & . & $\cdot / 4 \Delta q$ & $.1 . .1$ & F/TMY & T/Tr & جذابيت محيط \\
\hline
\end{tabular}

\section{بررسى شاخص هاى كالبدى - فضايى كيفيت زندكى}

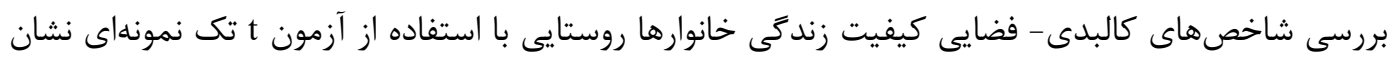

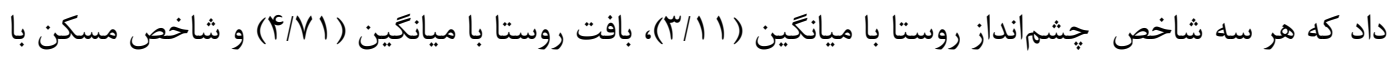


ميانكَين (T/T/T) در سطح مطلوبى قرار دارند. همانطورى كه يافتهها نشان مى دهد، با احتساب دامنه طيفى كه

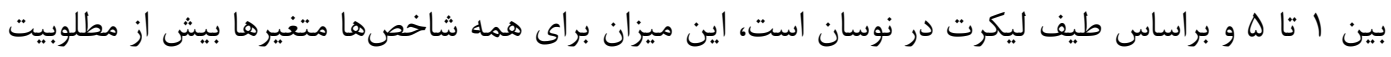

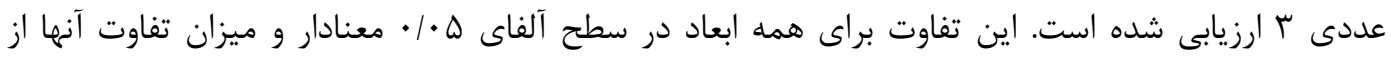

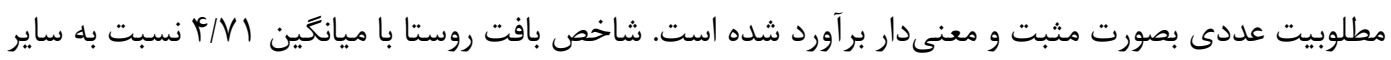

شاخصها در سطح بالاترى قرار دارد جدول (^).

جدول (^): بررسى شاخصهاى بعد كالبدى - فضايى

\begin{tabular}{|c|c|c|c|c|c|c|}
\hline \multicolumn{7}{|c|}{ مطلوبيت عددى مورد آزمون = } \\
\hline \multicolumn{2}{|c|}{ فاصله اطمينان هף درصد } & \multirow{2}{*}{ ميانكَين } & \multirow{2}{*}{ معنادارى } & \multirow{2}{*}{ 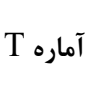 } & \multirow{2}{*}{ ميانكَين } & \multirow{2}{*}{ شاخص } \\
\hline حد بالا & حد بايين & & & & & \\
\hline.$\pi \Delta$ &.$- / 19$ & $\cdot 1 \cdot 11$ & $\cdot / . . r$ & $q / 4+\Delta$ & r/l & جشمانداز روستا \\
\hline $1 / \Lambda \Delta$ & $1 / \Delta r$ & 1/919 & 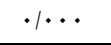 & $r 11.99$ & $F / N$ & بافت روستا \\
\hline$\cdot / A T$ &.$- / 11$ & $\cdot / / \Delta A$ & $\cdot \%$ & $11 / .4 \Delta$ & T/KT & مسكن \\
\hline
\end{tabular}

اثرات كردشكرى بر ابعاد كيفيت زندگى سكونتخاههاى روستايى

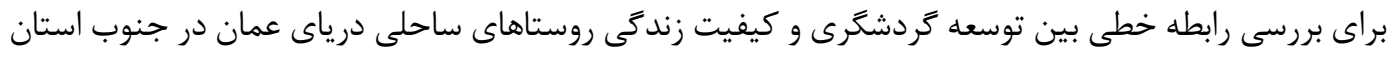

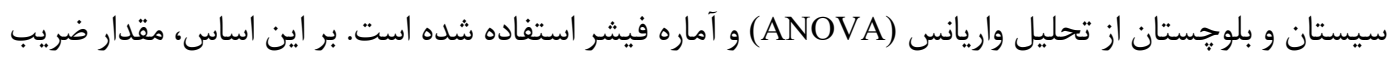

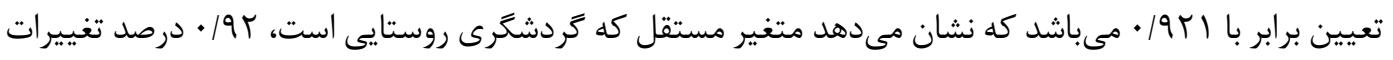

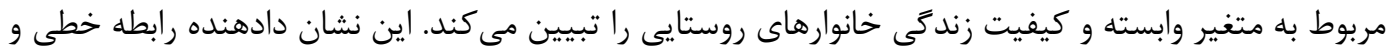

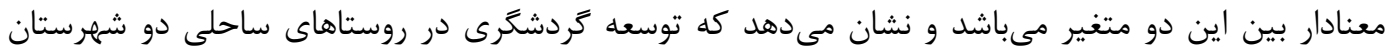

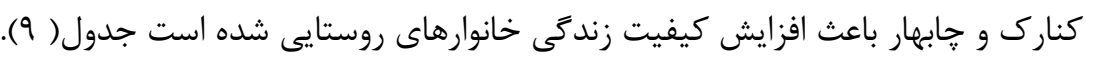
جدول (9): تحليل واريانس عوامل تاثير تذار بر كيفيت زندكى روستاييان

\begin{tabular}{|c|c|c|c|}
\hline اشتباه معيار & ضريب تعيين تصحيح شده & ضريب تعيين & صر يب همبستكى جندكانه \\
\hline سكקא. & .1 .91 &.$/ 9 T 1$ &.$\pi T \Delta$ \\
\hline
\end{tabular}

همجنين و بر اساس يافتههاى اين آزمون و با توجه به سطح معنىدارى كه كمتر از إ. • • مى باشد، مى توان كفت

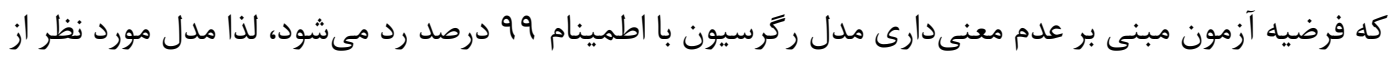

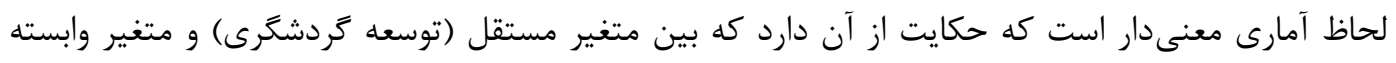

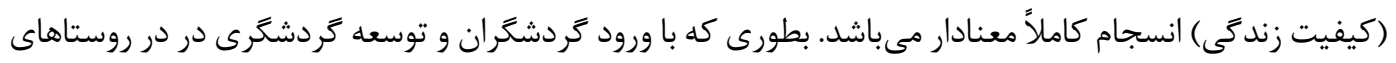

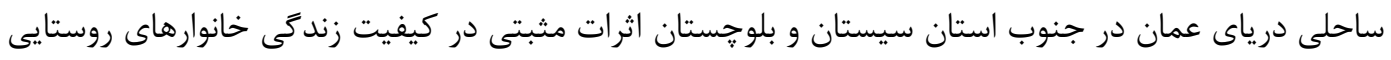

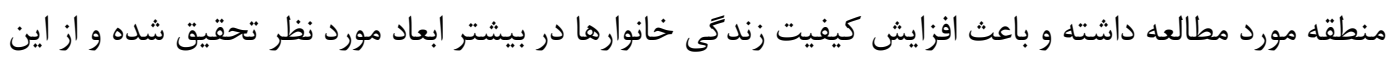
طريق باعث افزايش كيفيت زندگى خانوارهاى روستايى شده است جدول (· (1). 
جدول (•): تحليل واريانس مبتنى بر وجود رابطه خطى بين توسعه تردشعرى و كيفيت زندكى

\begin{tabular}{|c|c|c|c|c|c|}
\hline سطح معنادارى & F آماره F & ميانغين مربعات & درجه آزادى & مجموع مربعات & مؤلفهها \\
\hline \multirow[t]{3}{*}{$.1 \cdots$} & $N / M T$ & • & rF & $9 / \wedge \uparrow \Delta$ & اثر گرسيونى \\
\hline & & .1 .49 & TTY & IT/KTD & باقيمانده \\
\hline & & & $r \Delta \varphi$ & $r \pi / l V$. & كل \\
\hline
\end{tabular}

براى بررسى اثرات كردشخرى ساحلى در زمينه ابعاد مختلف كيفيت زندگى روستايى از مدل تحليل مسير استفاده

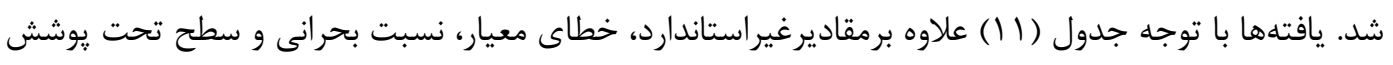

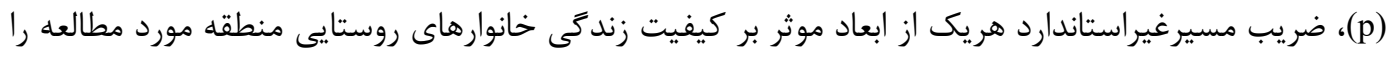

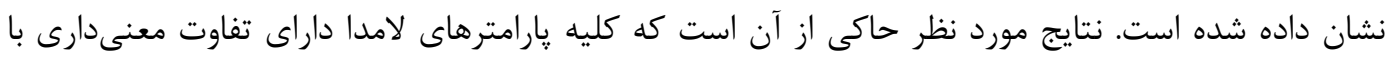

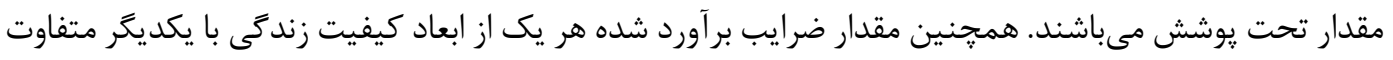

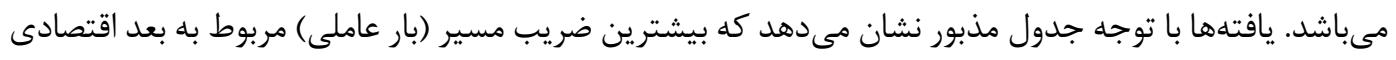

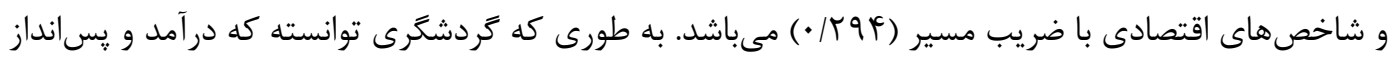

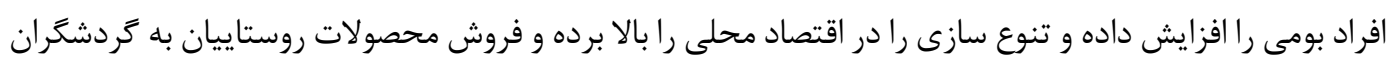

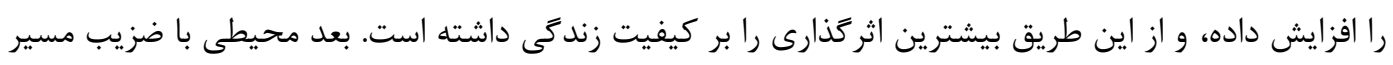

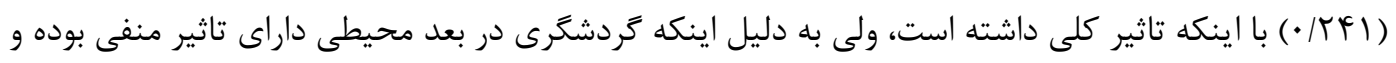

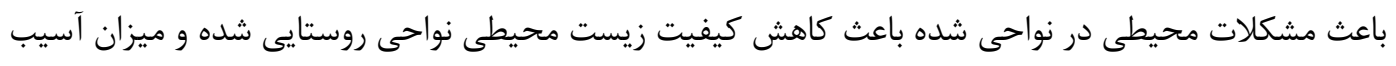

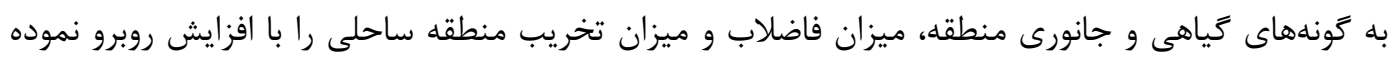

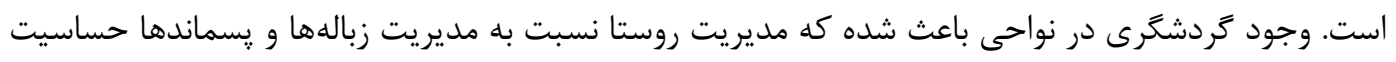

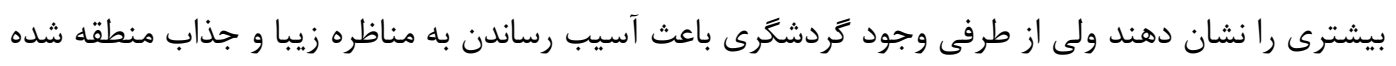

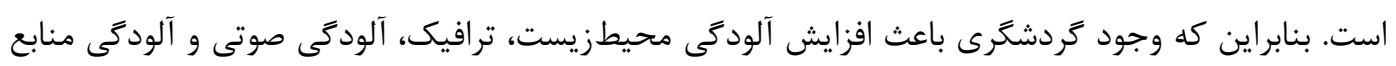

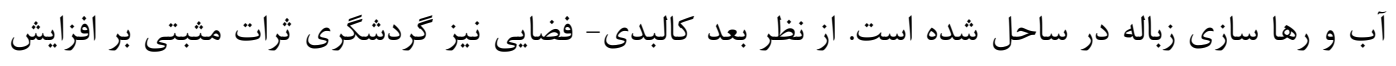

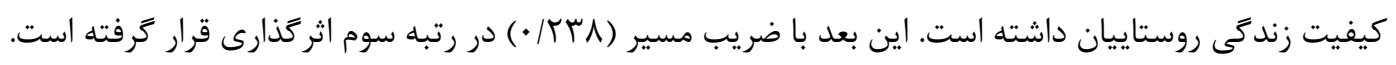

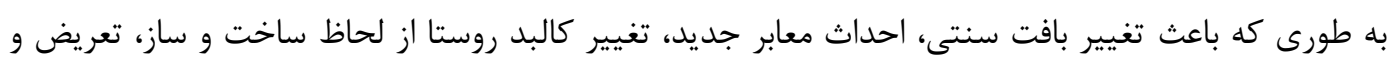

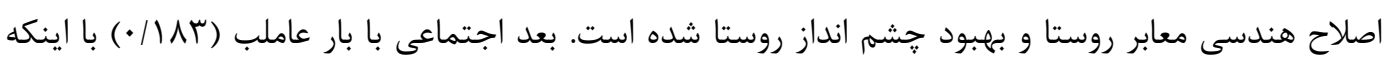

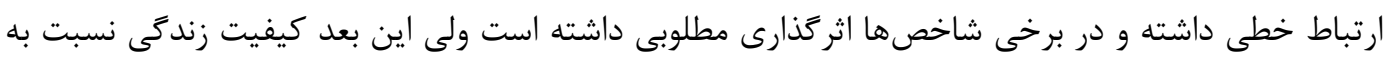

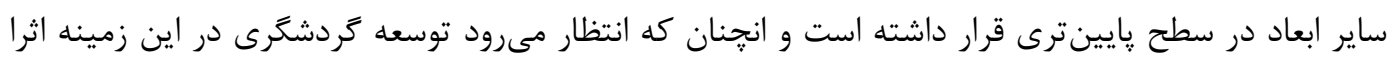

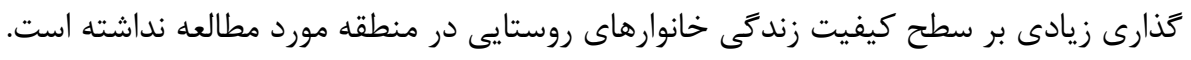

جدول (11): ضرايب و بار عاملى اثرات كردشغرى بر كيفيت زندكى آبرى

\begin{tabular}{|c|c|c|c|c|c|c|}
\hline معنى دارى & آماره ركر سيونى & خطاى استاندارد & ضريب مسير (بار عاملى) & 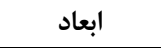 & & \\
\hline$\cdot / \cdots$ & $9 / 4 \cdot 4$ &.$|\cdot r|$ & $\cdot / r q 4$ & اقتصادى & ----> & كيفيت زندكى \\
\hline$\cdot 1 \cdots$ & $\Delta / \& V$. & .1 .19 & $\cdot / 1 \Lambda \mu$ & اجتماعى & ----> & كيفيت زندگى \\
\hline$\cdot / \ldots$ & $\mid Q / 8 \wedge 9$ & $.1 . .9$ & $\cdot \mid r+1$ & محيطى & ----> & كيفيت زندكى \\
\hline$\cdot 1 \ldots$ & $V / \| I T$ & . /.r. & N & كالبدى- فضايى & ----> & كيفيت زندكى \\
\hline
\end{tabular}




\section{نتيجه كيرى و غِيشنهادات}

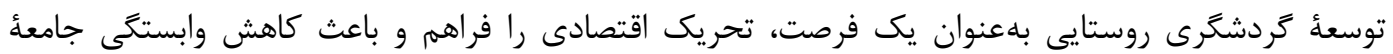

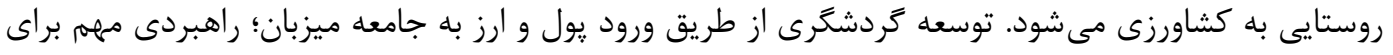

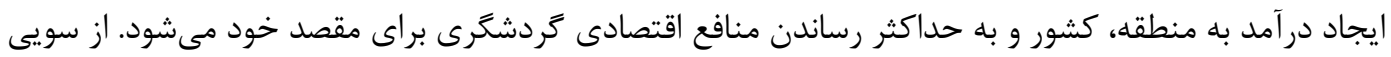

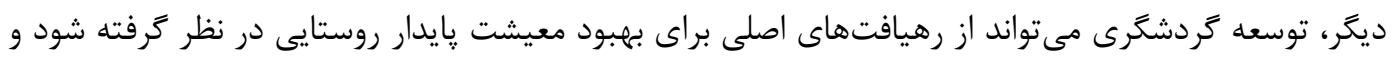

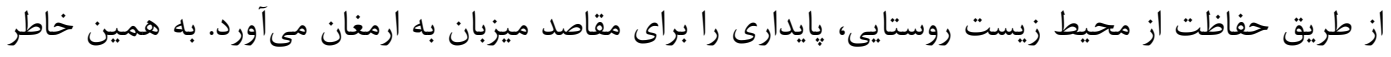

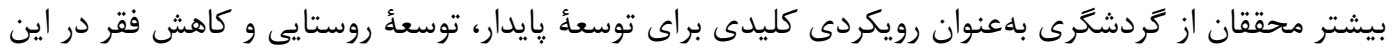

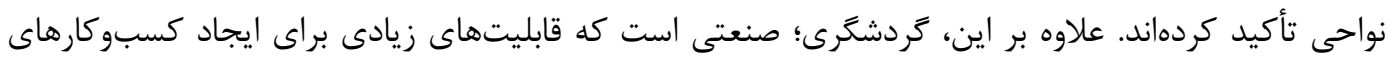

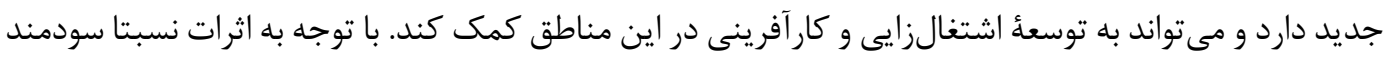

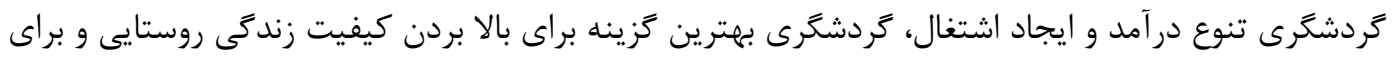

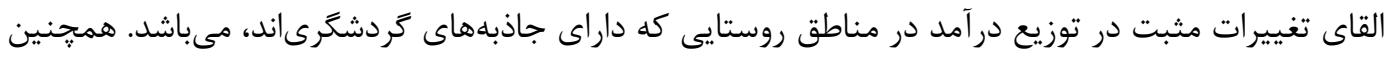

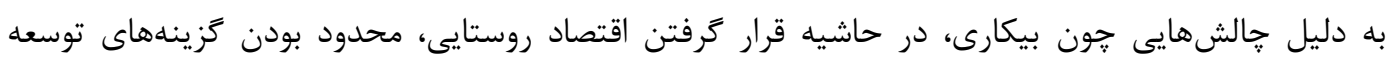

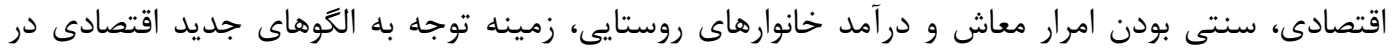

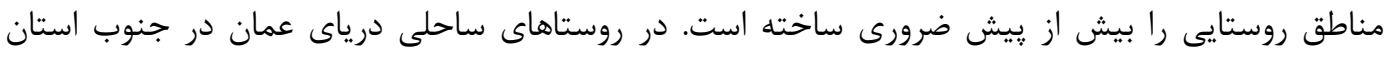

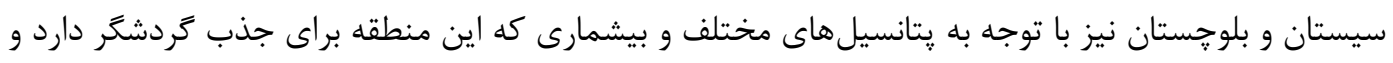

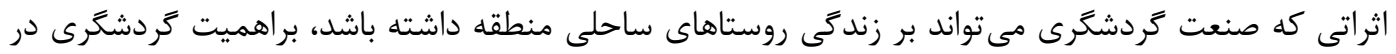

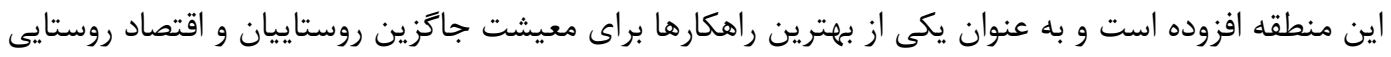

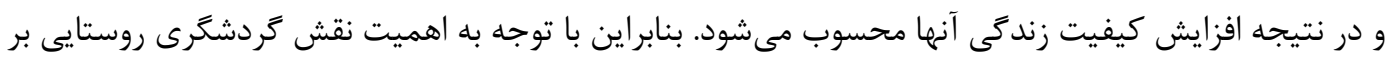

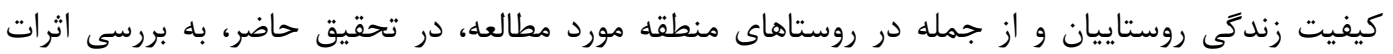

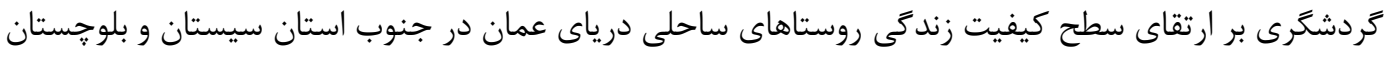

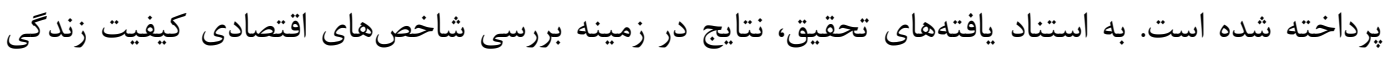

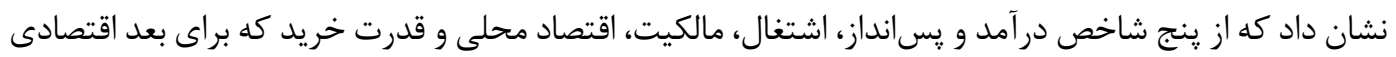
در نظر كرفته شد، به جز شاخص مالكيت، ساير شاخصهاى اقتصادى در سطح مطلوبى قرار داشتند. از بين اين

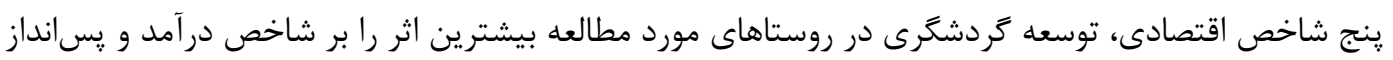

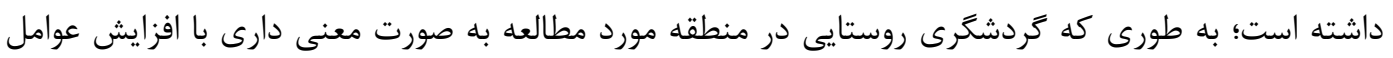

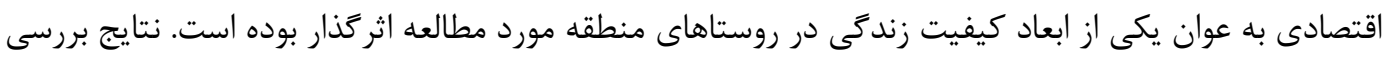

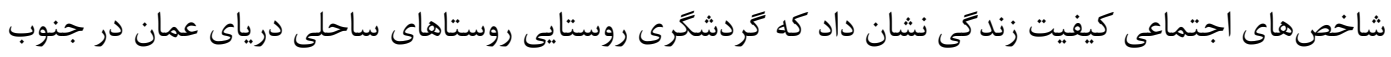

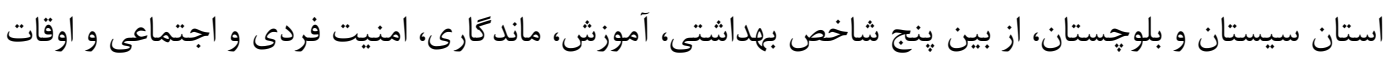

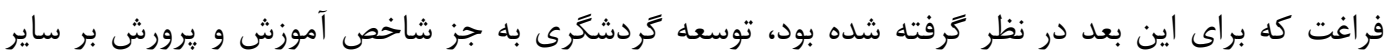

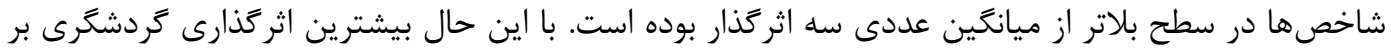

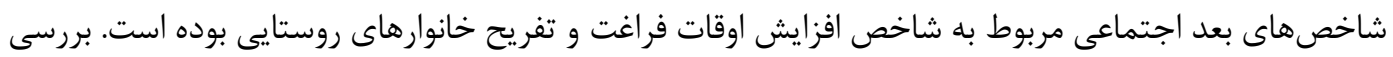

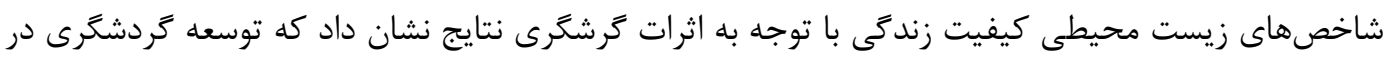


منطقه مورد مطالعه بر هر دو شاخص اين بعد اثر كذار بوده است. اين اثر كذارى گردشكرى بر دو شاخص كيفيت

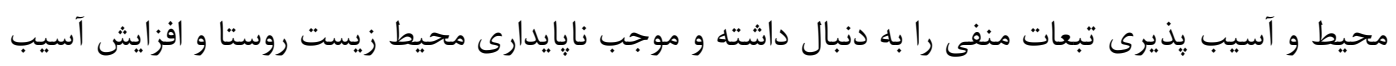

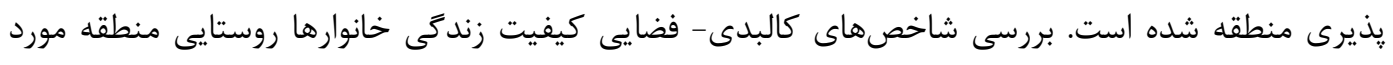

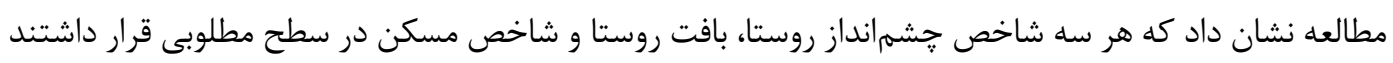

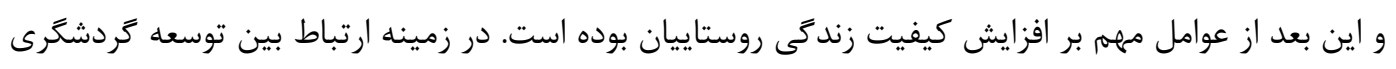

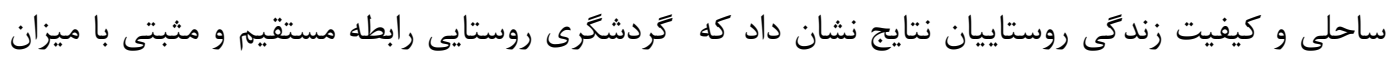

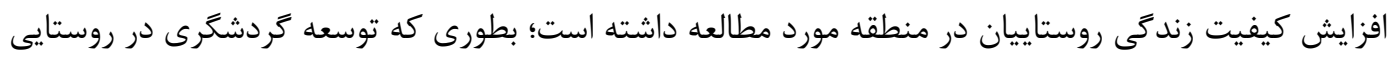

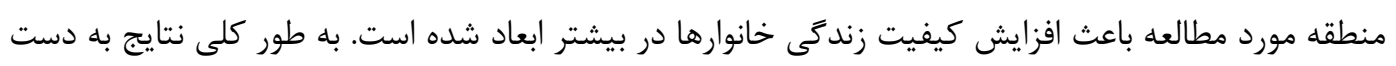

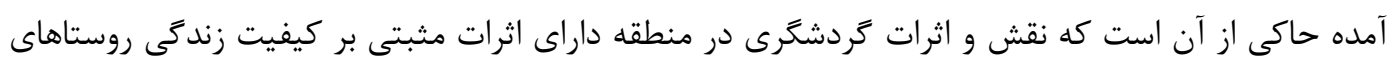

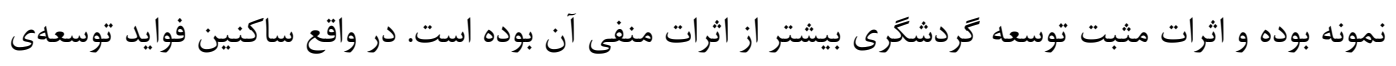

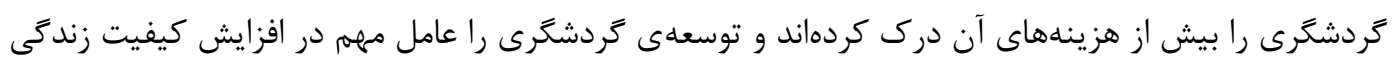

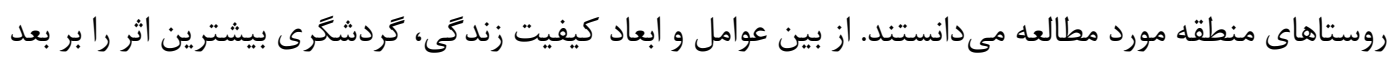

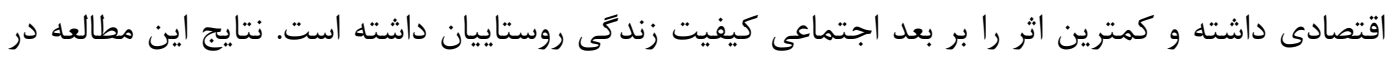

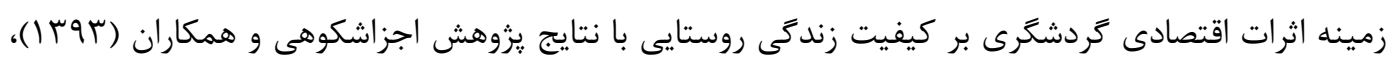

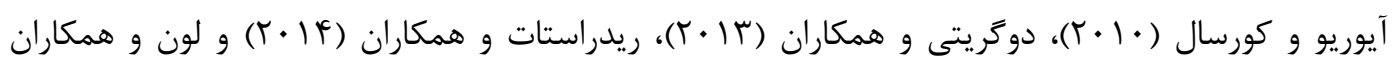

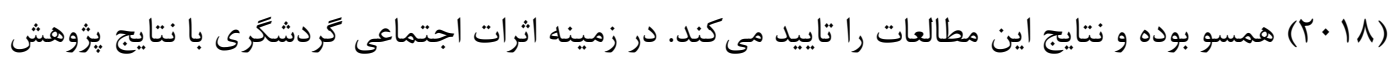

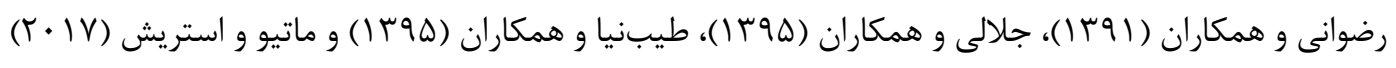

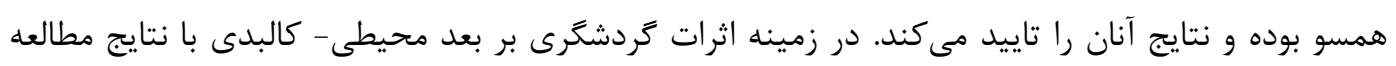

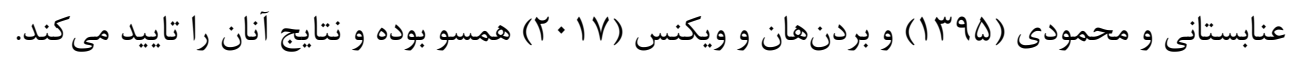

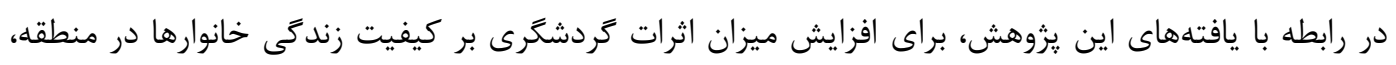

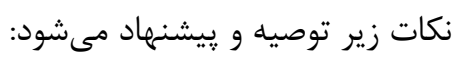

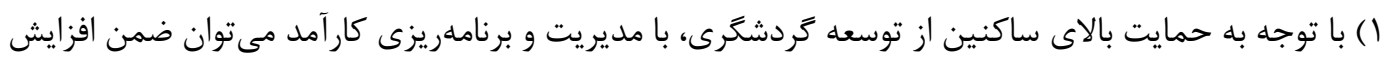

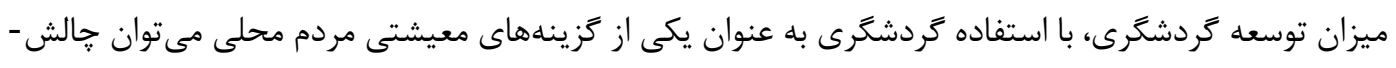

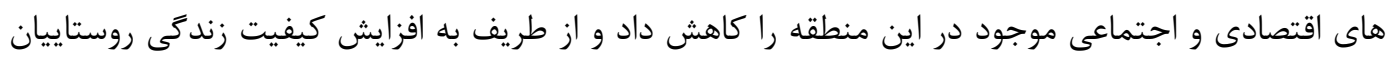
كمك نمود. ז) با مديريت اصولى از كردشكرى، مى توان آثار منفى آن در ناحيه مورد مطالعه كاهش داد كه اين امر به نوبه

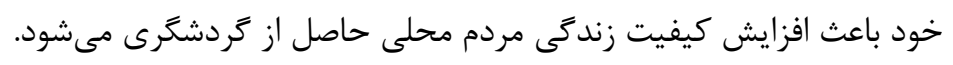

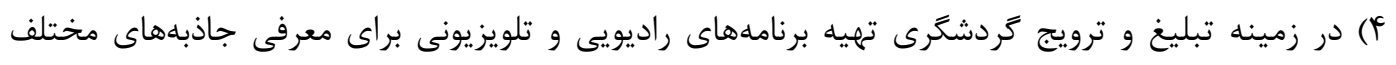

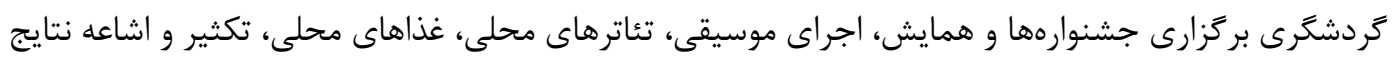

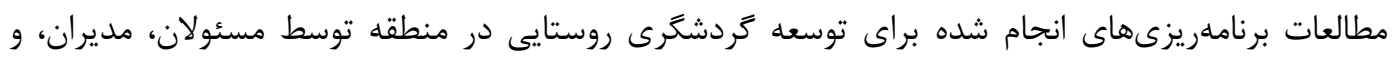

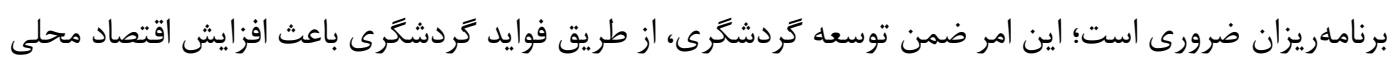
و كيفيت زندگى روستاييان مىشود. 
ه) فعاليتهاى خدماترسانى (مراكز خريد، نمايشكاههاى صنايع دستى و توليدات محلى، مكانهاى تفريحى در

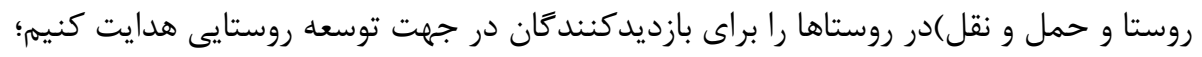

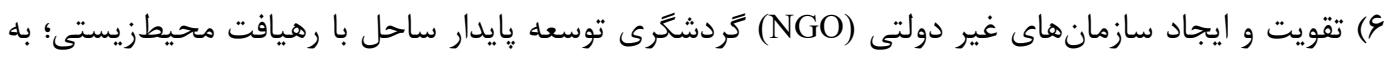

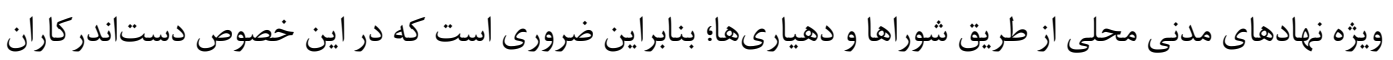

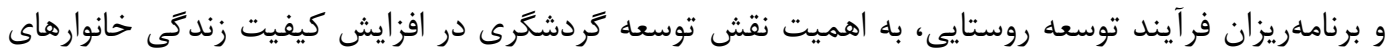
روستايى به طور اخص در منطقه مورد مطالعه و به صورت كلى در كل كشور توجه كافى داشته باشند.

منابع

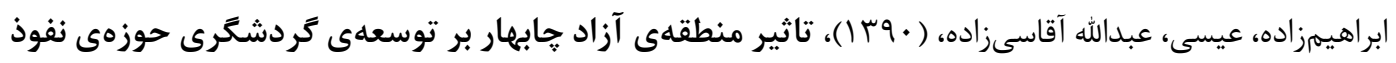

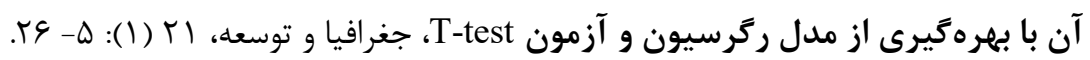

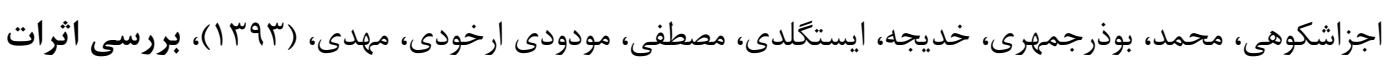

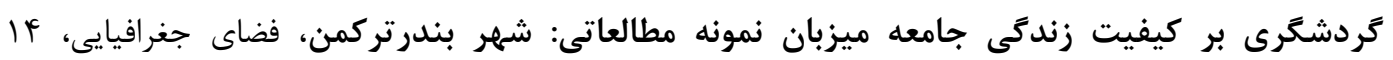

$.1 T Q-1 \cdot 1 \cdot($ P $Y$ V

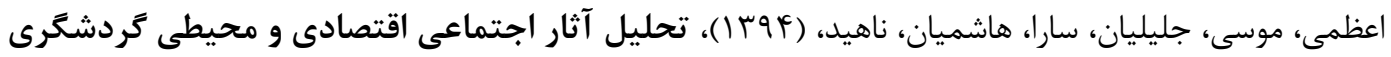

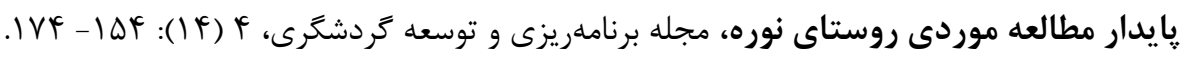

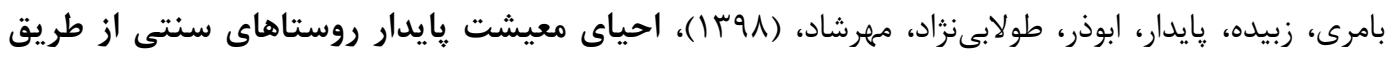

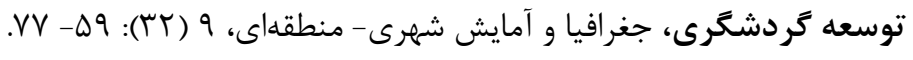

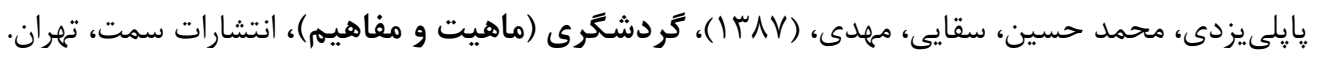

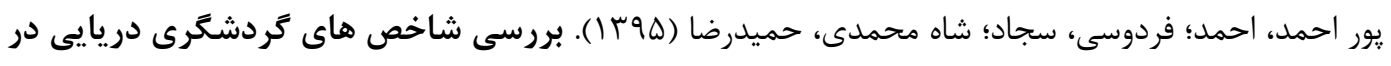

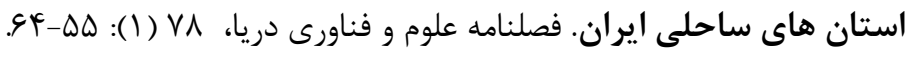

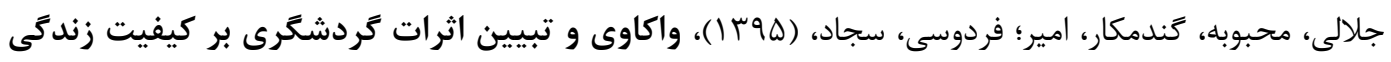

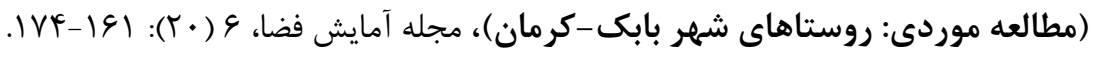

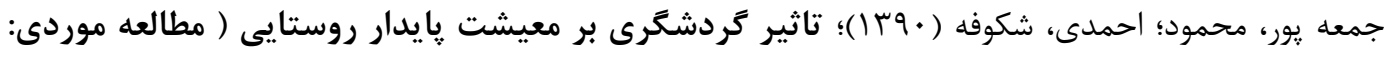

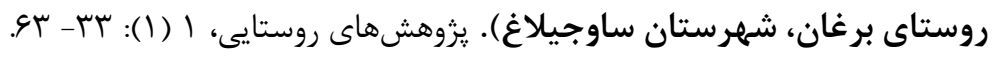

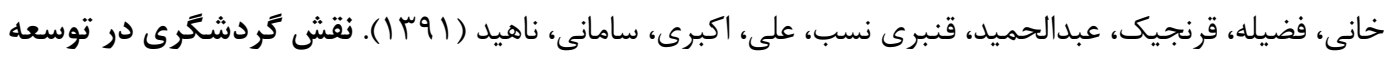

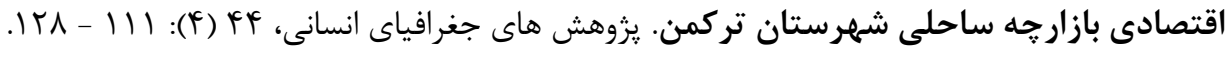

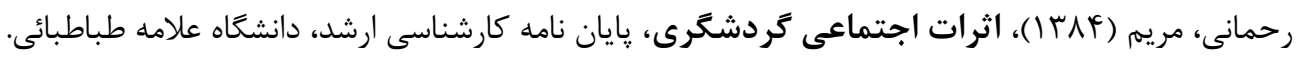

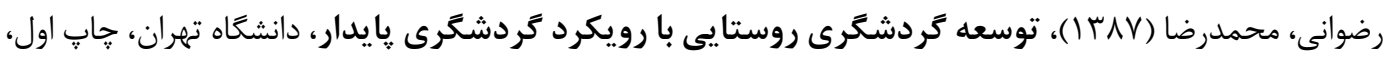
تهران. 


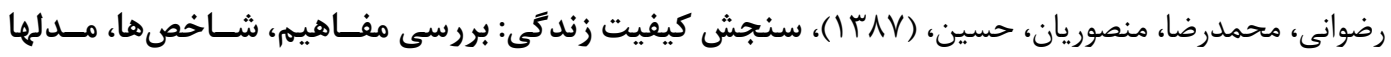

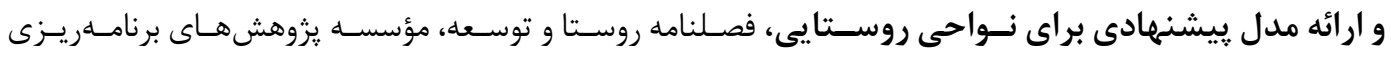

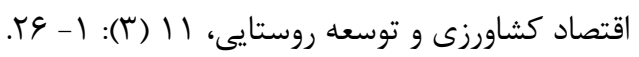

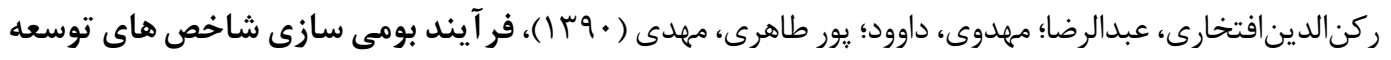

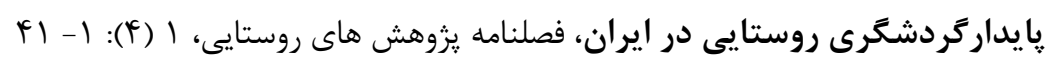

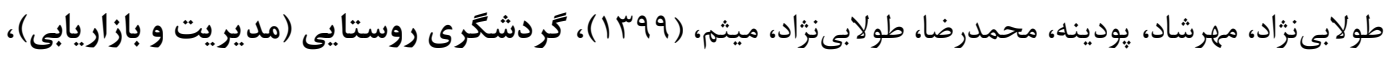

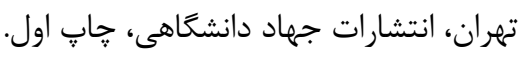

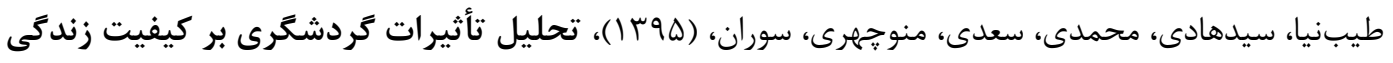

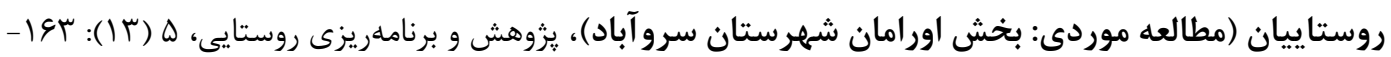

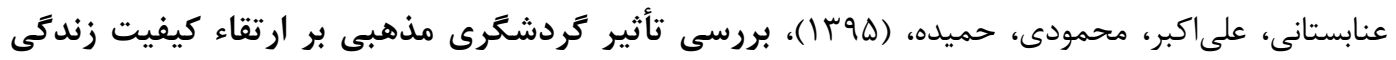

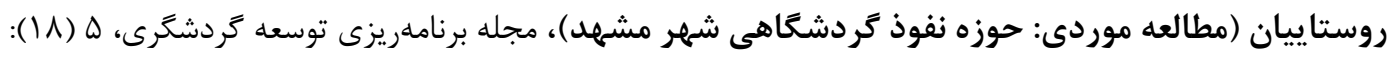

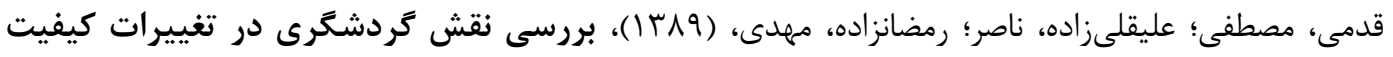

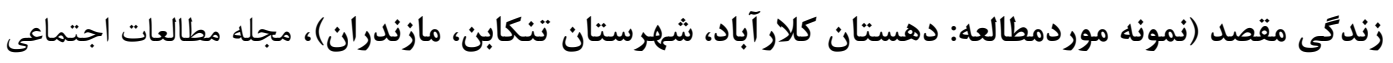

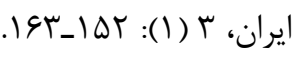

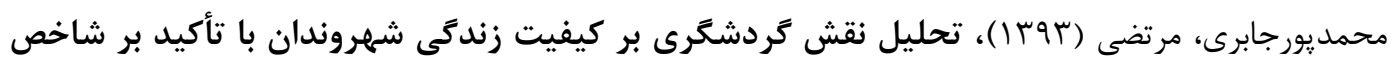

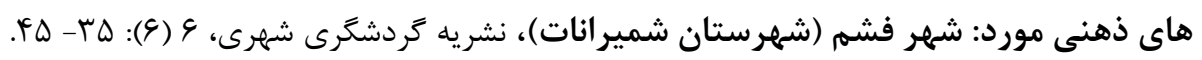

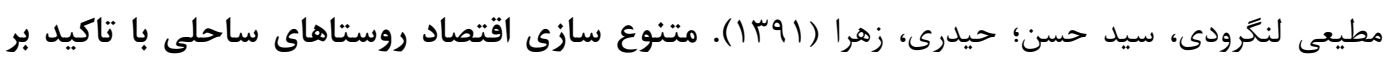

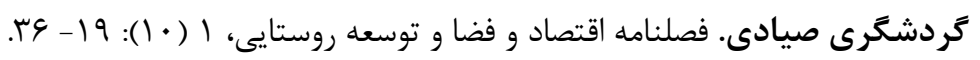

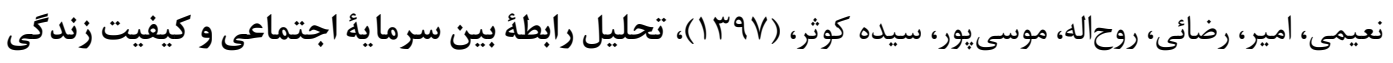

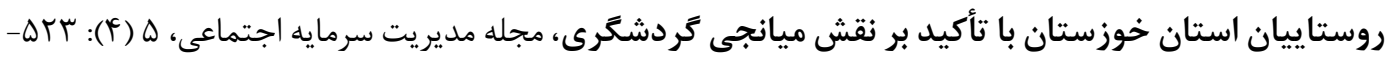

ياورى، حسين؛ خوشنويس، مريم؛ غلامى، الهام (19 (1). اقتصاد كردشگرى: انتشارات سيماى دانش، تهران. Briedenhann, J. and Wickens, E. (2017), Tourism routes as a tool for the economic development of rural areas vibrant hope or impossible dream? Tourism Management, 25 (2): 71-79.

Chim-Miki, A. F. Medina-Brito, P. and Batista-Canino, R. M. (2020), Integrated Management in Tourism: The Role of Coopetition, Tourism Planning and Development, 17 (2): 127-146.

Daniela Matei, F. (2015), Cultural tourism potential, as part of rural tourism development in the Northeast of Romania, Procedia Economics and Finance, 23 (1): 453- 460. 


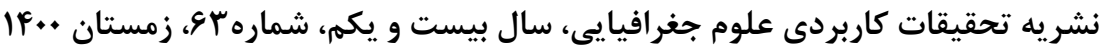

Dougherty Michael L., Brown Laura E. \& Green Gary Paul, (2013), The Social Architectur of Local Food Tourism: Challenges and Opportunitis for Community Economic Development, Journal of Rural Social Sciences, 28 (2): 1-27.

Dwyer, L. (2018), emerging ocean industries: implications for sustainable tourism development, Tourism in Marine Environments, 13 (1): 25- 40.

Farouh, H. E. El Din, H. S. Shalaby, A. and Elariane, S. A. (2013), Principles of urban quality of life for a neighborhood, HBRC Journal, 9: 86 -92.

Gao, J, Bihu $\mathrm{Wu}$, (2017), Revitalizing traditional villages through rural tourism: A case study of Yuanjia Village, Shaanxi Province, China, Tourism Management, 63 (1): 223-233. Gavrila-Pavena, I. (2015), Tourism opportunities for valorizing the authentic traditional rural space-study case: Ampoi and Mures Valleys micro region, Alba County, Romania, Procedia - Social and Behavioral Sciences, 188 (3): 276-281.

Gentle, P. and Maraseni, T. N. (2012), Climate change, poverty and livelihoods: adaptation practices by rural mountain communities in Nepal, Environmental Science \& Policy 21, 15 (1): 24- 34.

Guzman-Parra. V. F, Quintana-García. C, Benavides-Velasco. C A, and José Roberto VilaOblitas, (2015), Trends and seasonal variation of tourist demand in Spain: The role of rural tourism, Tourism Management Perspectives, 16 (3): 123-128.

Harilal, V. and Tichaawa, T. M. (2018), Ecotourism and Alternative Livelihood Strategies in Cameroon's Protected Areas, Euro Economics, 37 (2): 1- 26.

Jing, G, and Wu, B. (2017), Revitalizing traditional villages through rural tourism: A case study of Yuanjia Village, Shaanxi Province, China, Tourism Management, 63 (2): 223-233. Karadimitriou, C. Pappas, N. (2019), Virtual Reality and Nature Tourism. In: Tourism Naturally Conference, 4-6 June, Buxton, United Kingdom.

Lonn, P. Mizoue, N. Ota, T. Kajisa, T. and Yoshida, S. (2018), Evaluating the Contribution of Community-based Ecotourism (CBET) to Household Income and Livelihood Changes: A Case Study of the Chambok CBET Program in Cambodia, Ecological Economics, 151: 62- 69.

Mariana, B. Burgheleab, C. (2015), Rural tourism and its implication in the development of the Fundata Village, Procedia - Social and Behavioral Sciences, 188 (2): 276-281.

Marzo-Navarro. M, Pedraja-Iglesias. M, and Lucia Vinzón, (2016), Development and Validation of the Measurement Instruments ofthe Determinant Elements of Integrated Rural Tourism, Journal of Hospitality \& Tourism Research, 40 (4): 476-496.

Mathew, P. V. Sreejesh, S. (2017), Influence of responsible tourism on destination sustainability and quality of life of community in tourism destinations, Journal of Hospitality and Tourism Management, 31 (1): 83- 89.

Mathew, P. V. and Sreejesh, S. (2017), Impact of responsible tourism on destination sustainability and quality of life of community in tourism destinations, Journal of Hospitality and Tourism Management, 31 (2): 83-89.

Noronha, 1. (2002). Coastal tour ism, Environment, and sustainable Local. Development, London, TEPI, 2002.

Ridderstaat, J. Croes, R. and Nijkamp, N. (2014), the Tourism Development-Quality of Life Nexus in a Small Island Destination, Journal of Travel Research, 55 (1): 79- 94. 


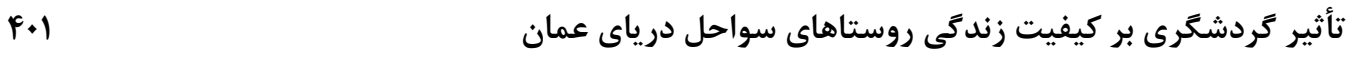

Shen, F., Hughey, K. F. D., and Simmons, D. G. (2008), Connecting the sustainable livelihoods approach and tourism: A review of the literature, Journal of Hospitality and Tourism Management, 15 (1): 19-31.

Smaranda, C. Dragos, P. Marius, B. Fleseriua, C. (2014), Innovation - a useful tool in the rural tourism in Romania, Procedia - Social and Behavioral Sciences,148: 507-515.

Smaranda, C. Dragos, P. Marius, B. Fleseriua, C. (2014), Innovation- a useful tool in the rural tourism in Romania, Procedia-Social and Behavioral Sciences, 148: 507-515.

Su. I, Huang. S, and Huang. J, (2016), Effects of Destination Social Responsibility and Tourism Impacts on Residents' Support for Tourism and Perceived Quality of Life, Journal of Hospitality \& Tourism Research, 2 (1): 1 -19.

$\mathrm{Wu}$, M.Y., Pearce, P.L., (2014). Host tourism aspirations as a point of departure for the sustainable livelihoods approach. J. Sustain. Tour. 22 (3): 440- 460.

Yang, Y. Fik, T. (2014), Spatial effects in regional tourism growth, Annals of Tourism Research, 46: 144- 162.

Zwiers. S, Markantoni. M. and Dirk Strijker, (2016), the role of change- and stabilityoriented place attachment in rural community resilience: a case study in south-west Scotland, Community Development Journal, 51 (4): 2- 20. 